\title{
Chloroquine and Hydroxychloroquine for the Prevention and Treatment of COVID-19: A Fiction, Hope or Hype? An Updated Review
}

\begin{abstract}
Sultan AM Saghir,' Naif A AIGabri,, ${ }^{2,3}$ Mahmoud M Alagawany, ${ }^{4}$ Youssef A Attia, ${ }^{5,6}$ Salem R Alyileili, ${ }^{7}$ Shaaban $S$ Elnesr, ${ }^{8}$ Manal E Shafi, ${ }^{9}$ Omar YA Alshargi, ${ }^{10}$ Nader Al-balagi,, "Abdullah S Alwajeeh, ${ }^{12}$ Omar SA Alsalahi, ${ }^{13}$ Amlan $\mathrm{K}$ Patra, ${ }^{14}$ Asmaa F Khafaga, ${ }^{15}$ Ahmed Negida, (ID) ${ }^{16,17}$ Ahmed Noreldin, ${ }^{18}$ Wesam Al-Amarat, (D) ${ }^{19}$ Amer A Almaiman, ${ }^{20}$ Khaled A El-Tarabily, (DD ${ }^{21,22}$ Mohamed E Abd El-Hack (D) ${ }^{4}$
\end{abstract}

'Department of Medical Analysis, Princess Aisha Bint AlHussein College of Nursing and Medical Sciences, AlHussein Bin Talal University, Ma'an, 7 I I I I, Jordan; ${ }^{2}$ Pathology Department, Faculty of Veterinary Medicine, Thamar University, Dhamar, Yemen; ${ }^{3}$ Laboratory of Regional Djibouti Livestock Quarantine, Abu Yasar International Est. I 999, Djibouti, Djibouti; ${ }^{4}$ Department of Poultry, Faculty of Agriculture, Zagazig University, Zagazig, 445I I, Egypt; 'Department of Agriculture, Faculty of Environmental Sciences, King Abdulaziz University, Jeddah, 21589, Kingdom of Saudi Arabia; ${ }^{6}$ Department of Animal and Poultry Production, Faculty of Agriculture, Damanhour University, Damanhour, Egypt; ${ }^{7}$ Department of Integrative Agriculture, College of Food and Agriculture, United Arab Emirates University, Al-Ain, I555I, United Arab Emirates; ' Department of Poultry Production, Faculty of Agriculture, Fayoum University, Fayoum, 635/4, Egypt: ${ }^{\circ}$ Department of Biological Sciences, Zoology, King Abdulaziz University, Jeddah, 21589 , Kingdom of Saudi Arabia; ${ }^{10}$ Department of Pharmacology, College of Pharmacy, Riyadh Elm University, Riyadh, Kingdom of Saudi Arabia; "'Ministry of Health, Riyadh, Kingdom of Saudi Arabia; ${ }^{12}$ AntiDopingLab, Doha, Qatar; ${ }^{13}$ Department of Medical Laboratories, Faculty of Medicine and Health Sciences, Hodeidah University, Al Hodaidah, Yemen; ${ }^{14}$ Department of Animal Nutrition, West Bengal University of Animal and Fishery Sciences, Belgachia, Kolkata, India;

${ }^{15}$ Department of Pathology, Faculty of Veterinary Medicine, Alexandria University, Edfina, 22758, Egypt;

${ }^{16}$ School of Pharmacy and Biomedical Sciences, University of Portsmouth, Portsmouth, UK; ${ }^{17}$ Zagazig University Hospitals, Faculty of Medicine, Zagazig University, Zagazig, Egypt; ${ }^{18}$ Histology and Cytology Department, Faculty of Veterinary Medicine, Damanhour University, Damanhour, 225I I, Egypt; ${ }^{19}$ Department of Medical Support, AlKarak University College, Al-Balqa' Applied University, Salt, Jordan; ${ }^{20}$ Department of Applied Medical Sciences, Community College of Uniazah, Qassim University, Buraydah, 5 I43I, Kingdom of Saudi Arabia;

${ }^{2}$ Department of Biology, College of Science, United Arab Emirates University, Al-Ain, I555I, United Arab Emirates: ${ }^{22}$ Biosecurity and One Health Research Centre, Harry Butler Institute, Murdoch University, Murdoch, Western Australia, 6150, Australia

Correspondence: Youssef A Attia; Khaled A El-Tarabily Email yaattia@kau.edu.sa; ktarabily@uaeu.ac.ae

\begin{abstract}
In December 2019, the novel coronavirus disease pandemic (COVID-19) that began in China had infected so far more than 109,217,366 million individuals worldwide and accounted for more than 2,413,912 fatalities. With the dawn of this novel coronavirus (SARS-CoV-2), there was a requirement to select potential therapies that might effectively kill the virus, accelerate the recovery, or decrease the case fatality rate. Besides the currently available antiviral medications for human immunodeficiency virus (HIV) and hepatitis $\mathrm{C}$ virus (HCV), the chloroquine/hydroxychloroquine (CQ/HCQ) regimen with or without azithromycin has been repurposed in China and was recommended by the National Health Commission, China in mid-February 2020. By this time, the selection of this regimen was based on its efficacy against the previous SARS-CoV-1 virus and its potential to inhibit viral replication of the SARS-CoV-2 in vitro. There was a shortage of robust clinical proof about the effectiveness of this regimen against the novel SARS-CoV-2. Therefore, extensive research effort has been made by several researchers worldwide to investigate whether this regimen is safe and effective for the management of COVID-19. In this review, we provided a comprehensive overview of the $\mathrm{CQ} / \mathrm{HCQ}$ regimen, summarizing data from in vitro studies and clinical trials for the protection against or the treatment of SARS-CoV-2. Despite the initial promising results from the in vitro studies and the widespread use of CQ/HCQ in clinical settings during the 1st wave of COVID-19, current data from well-designed randomized controlled trials showed no evidence of benefit from CQ/HCQ supplementation for the treatment or prophylaxis against SARS-CoV-2 infection. Particularly, the two largest randomized controlled trials to date (RECOVERY and WHO SOLIDARITY trials), both confirmed that $\mathrm{CQ} / \mathrm{HCQ}$ regimen does not provide any clinical benefit for COVID-19 patients. Therefore, we do not recommend the use of this regimen in COVID-19 patients outside the context of clinical trials.
\end{abstract}

Keywords: antiviral drugs, chloroquine, COVID-19, drug safety, hydroxychloroquine, SARS-CoV-2, treatments

\section{Introduction}

Coronavirus disease-2019 (COVID-19) is a disease pandemic caused by a new strain of coronavirus called severe acute respiratory syndrome coronavirus 2 (SARS-CoV-2). ${ }^{1}$ Formerly, this disease was referred to as '2019 novel coronavirus' or "2019-nCoV." The virus name (SARS-CoV-2) was chosen because the virus is genetically related to the coronavirus responsible for the SARS outbreak of 2003. ${ }^{1}$ While related, the two viruses are different. ${ }^{1}$ The spread of SARS-CoV-2 began in Wuhan, China, by the end of December $2019 .^{2}$ As of February 17, 2020, the 
COVID-19 pandemic has swept the world and infected more than 109,217,366 million individuals worldwide and accounted for more than 2,413,912 fatalities. ${ }^{2}$

The initial case fatality rate of this virus was estimated to be $2 \%$ but ranged in some countries from 4 to $9 \%$. After adjustment for asymptomatic cases, this virus's actual fatality rate was estimated to be around $1 \%$. The major challenge of COVID-19 is the rapid transmission of the virus and the substantial proportion of asymptomatic individuals who accounted for $40-50 \%$ of transmission. ${ }^{3}$

Extensive efforts are being made to fight this virus, including both pharmacological and non-pharmacological interventions. In the search for potential pharmacologic agents that might be useful to protect against the virus and/or treat COVID-19 patients, clinicians have repositioned chloroquine (CQ) and hydroxychloroquine (HCQ) as a treatment regimen. ${ }^{3}$ The rationale for selecting this regimen in the early months of the pandemic was the following: (1) This regimen has been previously utilized for the cure against SARS-CoV-1 with documented success, and (2) recent in vitro experiments in China showed that these agents could inhibit viral replication in vitro. ${ }^{3}$

Since then, this regimen has divided the world with one extreme trolling it as "game changer in medicine" while other touting it as 'useless and dangerous'. Therefore, in the present article, we provide a comprehensive review of the use of $\mathrm{CQ} / \mathrm{HCQ}$ regimen with or without azithromycin, illustrating the structure, mechanism of action, side effects and drug interactions, and experimental studies data, and data of clinical trials.

\section{Structure of the SARS-CoV-2 Virus}

Coronaviruses are spherical with an average diameter of 80-120 nm. They possess a number of club-shaped (17-20 $\mathrm{nm}$ ) glycoproteins spikes projecting from the surface of the viral envelope. ${ }^{4}$ The virus particle contains five major structural proteins, which are glycoprotein spikes $(\mathrm{S})$, an envelope protein $(\mathrm{E})$, matrix protein $(\mathrm{M})$, and nucleocapsid (N) protein. ${ }^{4}$ The glycoprotein spikes mediate virus's attachment to different host cell receptors, depending upon the receptor-binding domain (RBD). On attachment to the host cell receptor, the glycoprotein spikes $\mathrm{S}$ protein cleavages into two subunits, namely, N-terminal S1 and C-terminal S2 subunit regions by the host proteases enzyme. ${ }^{4}$ S1 subunit contains a signal peptide and a RBD. Meanwhile, S2 subunit contains conserved fusion peptide (FP), heptad repeat (HR) peptides, transmembrane domain (TM), and a cytoplasmic domain. ${ }^{4}$
The S1 subunit of SARS-CoV-2 showed 70\% identity to Beta coronavirus's $\mathrm{S} 1$ subunits (SARS-CoV-1) isolated from human and bats. ${ }^{5}$ Human angiotensin-converting enzyme 2 (hACE2) acts as the key receptor to infect the human cells..$^{5}$ The S2 subunit plays an important role in mediating the virus fusion and entry into the host cell, in which heptad repeat 1 and 2 (HR1, HR2) can interact with six helical bundles, thereby bringing the viral and cellular membrane in close proximity for fusion. ${ }^{5}$

The ACE2-binding affinity of RBD in $\mathrm{S} 1$ subunit of SARS-CoV-2 is 10 to 20 -fold higher, which might contribute to the higher infectivity and transmissibility of SARS-CoV-2 compared to SARS-CoV-1. ${ }^{5}$ The $\mathrm{M}$ glycoprotein is pre-glycosylated $\mathrm{M}$ polypeptides with a size range of $25-30 \mathrm{kDa}$ (221-262 amino acids) and gives shape to the virus envelope. ${ }^{5}$ Envelope protein $(\mathrm{E})$ is a small polypeptide with a size range of 8.4-12 kDa (76109 amino acids) and is the integral membrane protein.,

\section{Chemical Compositions and Sources of $\mathrm{CQ}$ and $\mathrm{HCQ}$}

CQ and HCQ have similar chemical structures and cellular mechanisms of action. ${ }^{3} \mathrm{CQ}$ is administered as a phosphate salt, whereas HCQ is administered as a sulfate. Both drugs are absorbed in the upper intestinal tract. ${ }^{6}$ The CQ is produced by systematic modification of quinine, which is a plant alkaloid and quinoline containing compound. ${ }^{7}$ Hans Andersag discovered CQ in 1934 at the Bayer laboratory and named it "Resochin". It became available in clinical practice in 1947 and quickly became the drug of choice for the treatment of malaria. ${ }^{7}$

CQ, 7-chloro-4-(4-diethylamino-1-methylbutylamino)quinoline is made by reacting 4-diethylamino-1-methylbutylamine with 4,7 -dichloroquinoline at $180^{\circ} \mathrm{C} .{ }^{8}$ Each of the two components involved in CQ synthesis can be prepared in several ways (Figure 1). In 1946, HCQ sulfate was synthesized as a derivative of CQ by incorporating a hydroxyl group into $\mathrm{CQ}$, and they both share comparable mechanisms of action as weak bases and immuno-modulators. ${ }^{3}$

It was proved that CQ is two to three times as toxic in animals as HCQ. ${ }^{9}$ More interestingly, HCQ, compared with $\mathrm{CQ}$, is vastly available to cure auto-immune diseases like rheumatoid arthritis and systemic lupus erythematosus. ${ }^{10}$

\section{Mechanism of Action of $\mathrm{CQ}$ and $\mathrm{HCQ}$}

Both CQ and HCQ are weak bases that increase the $\mathrm{pH}$ of acidic intracellular organelles like lysosomes/endosomes 


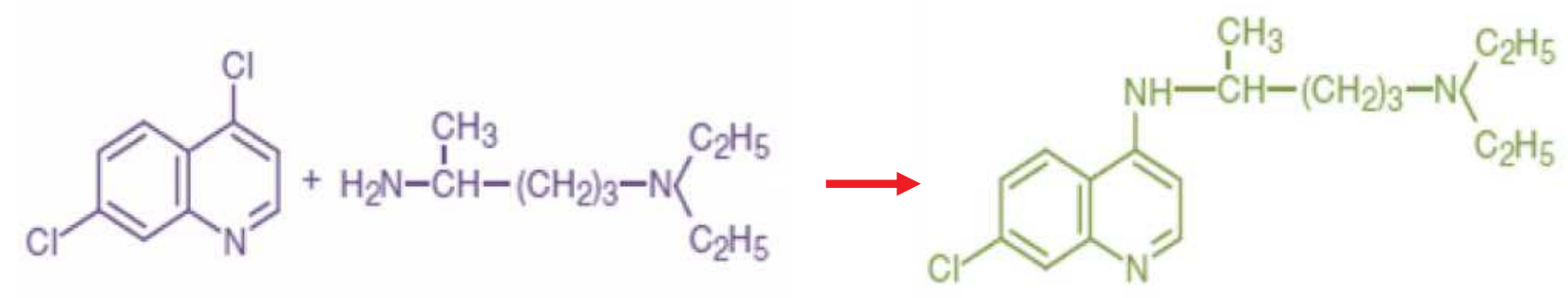

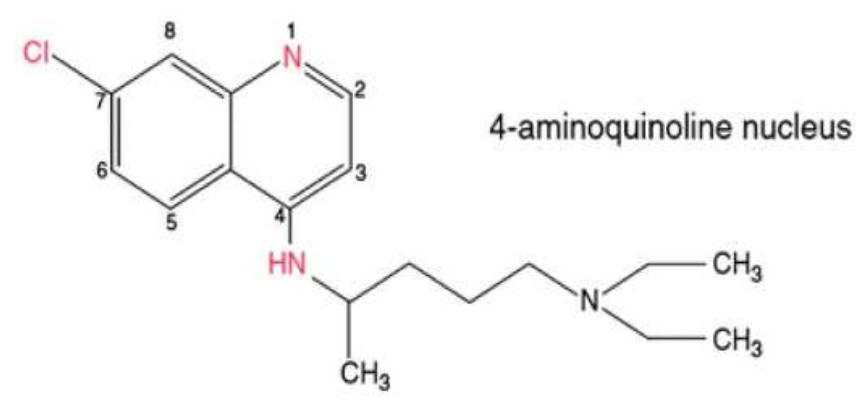

Chloroquine

Figure I Chemical composition of chloroquine and hydroxychloroquine.

that require low $\mathrm{pH}$ for maturation and function. ${ }^{11} \mathrm{CQ}$ showed elevation in $\mathrm{pH}$ of lysosomes from nearly 4.5 to 6.5 at $100 \mu \mathrm{M}$. However, the effect of HCQ on $\mathrm{pH}$ values of lysosomes/endosomes is not known due to the lack of studies in this regard. ${ }^{3}$

Moreover, CQ was found to cause changes in the glycosylation of ACE2 spike protein and receptor that ultimately inhibits the entry step and the post-entry phase of SARS-CoV $-2 .{ }^{12} \mathrm{HCQ}$ in the time-of-addition experiment showed its ability to exert the same mechanism (Figure 2).

In addition to the previously known mechanism, a novel mechanism of action for CQ and HCQ on COVID-19 was discovered in 2020 by Fantini et $\mathrm{al}^{13}$ as it is known that SARS-CoV-2 starts its replication by attaching to the spike (S) viral protein of respiratory cells. ${ }^{13}$ The $\mathrm{S}$ protein utilizes sialic acids and ACE-2 receptor connected to host cell surface gangliosides for entry. The study showed that CQ (or its more active derivative, HCQ) has a high affinity for binding to gangliosides and sialic acids. ${ }^{13}$

The study also distinguished a novel gangliosidebinding domain (111-158) at the tip of the N-terminal domain of the SARS-CoV-2 S protein. It is expected that this domain can ease attachment with the ACE-2 receptor and enhance contact of the virus to lipid rafts. ${ }^{13}$

\section{Side Effects of the CQ/HCQ Treatment}

High doses of CQ were found to cause severe side effects, but it was reported that CQ in a prescribed dose exerts relatively few adverse effects. ${ }^{14}$ Ocular adverse effects such as long and subtle symptoms of reduced visual acuity, diplopia, retinal toxicity, and bilateral loss of vision were found to be the most severe side effects caused by high doses of CQ. ${ }^{15}$ A high dosage of CQ also causes critical psychiatric issues such as hallucinations, paranoia, and suicidal ideations. ${ }^{16}$ Injecting CQ intramuscularly has shown to cause potentially life-threatening hypotension. ${ }^{17}$

Other adverse effects include pruritus, photosensitivity, seizures, paranoia, hallucinations, and retinopathy characterized by the inability to focus on near and far objects ${ }^{18}$ (Figure 3). HCQ has a more solubility and less toxic metabolites compared with CQ. Hence, it has fewer adverse effects and is relatively safer. ${ }^{19}$ For these reasons, HCQ is often preferred over CQ where possible. ${ }^{18}$ 


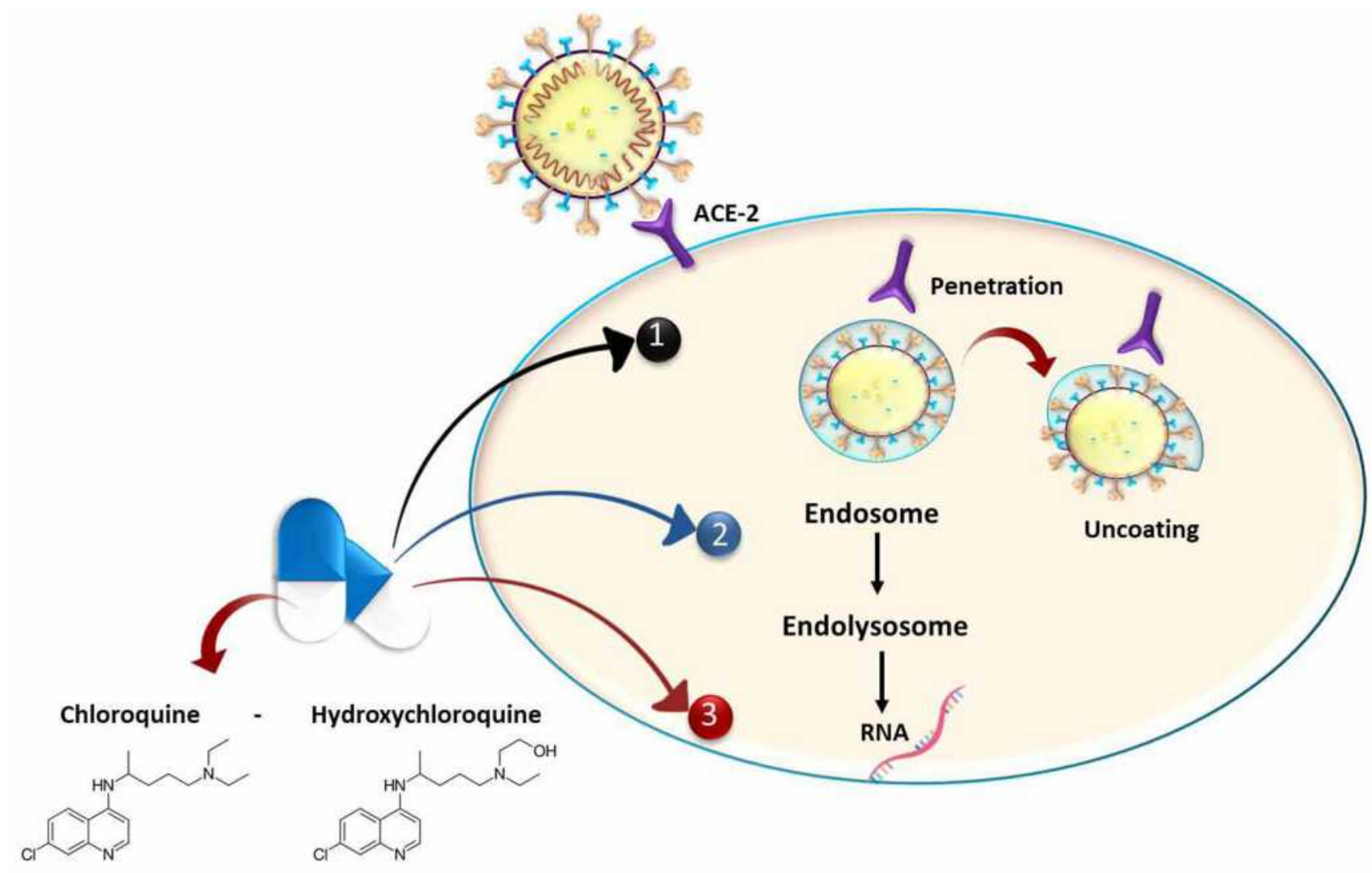

Figure 2 The possible mode of action of chloroquine and hydroxychloroquine versus SARS-CoV-2 infection: (I) interference with the terminal glycosylation of cellular receptor angiotensin-converting enzyme 2 (ACE-2) leads to obstructing virus-receptor attachment; (2) increasing the $\mathrm{pH}$ of acidic cellular organelles lead to prevention of endocytosis with adverse influences on post-translational modification of recently synthesized viral RNA and virion transport; (3) blocking of viral protein synthesis and virion assembly.

\section{Cautions and Contraindications}

Patients receiving CQ or/and HCQ must be monitored for their haematological parameters (RBC, WBC, and platelet counts), blood glucose (hypoglycemic risk of HCQ), serum electrolytes, renal as well as hepatic functions. ${ }^{20}$ Electrocardiography (ECG) is essential before starting therapy with these medications and the concomitant use of these drugs with other drugs known to extend the corrected QT (QTc) interval of the heart (like antihistamines, anti-depressants, anti-arrhythmic, anti-psychotics, moxifloxacin, teneligliptin, and ondansetron) should be averted. ${ }^{21}$ The addendum of HCQ to azithromycin, as reported by Gautret et $\mathrm{al}^{22}$ in the French trial, may elevate QTc extension. ${ }^{23}$ If QTc is $450-500 \mathrm{msec}$, it is recommended to do daily ECG. CQ and HCQ must not be utilized simultaneously with ritonavir/lopinavir and remdisivir for expected QTc extension. Additionally, hypoglycaemia should be observed in diabetes patients, particularly with concomitant usage of $\mathrm{CQ} / \mathrm{HCQ}$ and ritonavir/lopinavir. ${ }^{23}$
Pharmacovigilance on the mental and visual disorder is also carefully wanted (Figure 4).

Despite case reports of reversible heart failure and CQinduced cardiomyopathy in the literature, large metaanalysis and numerous investigations carried out in patients having rheumatoid arthritis confirmed a lowered cardiovascular hazard with both drugs; nonetheless, a baseline ECG must be completed in patients with certain cardiovascular disease. ${ }^{24}$ Every clinician utilizing these drugs should realize contraindications to both compounds; porphyria, pre-existing maculopathy, retinopathy, glucose6-phosphate dehydrogenase deficiency, epilepsy, recent myocardial infarction, hypersensitivity to these agents, and QTc $>500$ msec. $^{20}$ There is no evidence that CQ and HCQ are contraindicated in lactating and pregnant women. ${ }^{25}$

It is worth noticing that CQ and HCQ interact with various drugs; many lead to QT prolongation and might lead to serious cardiac events and death. As mentioned earlier, this includes patients who take the $\mathrm{CQ} / \mathrm{HCQ}$ 


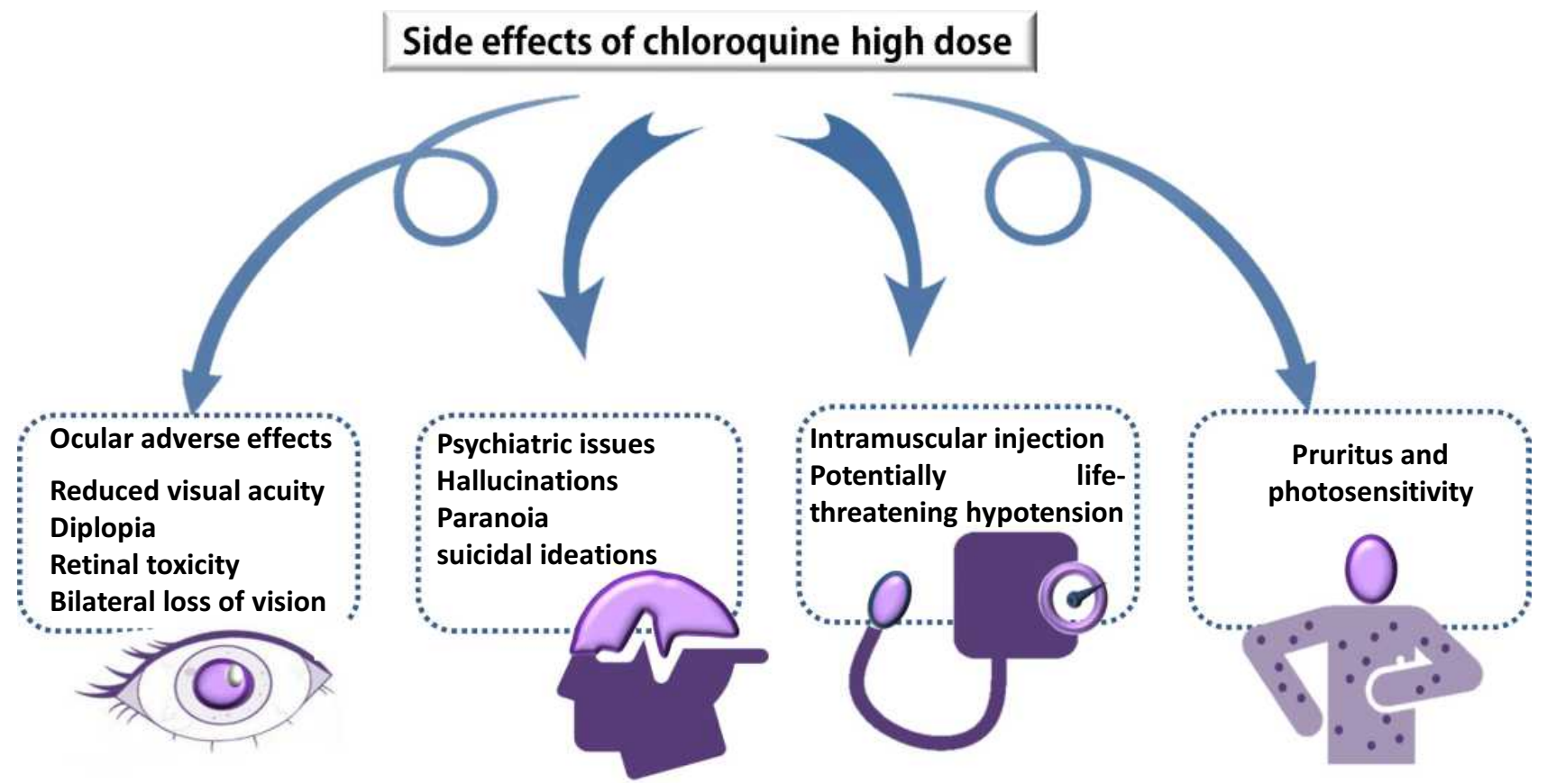

Figure 3 The possible side effects of chloroquine and hydroxychloroquine.

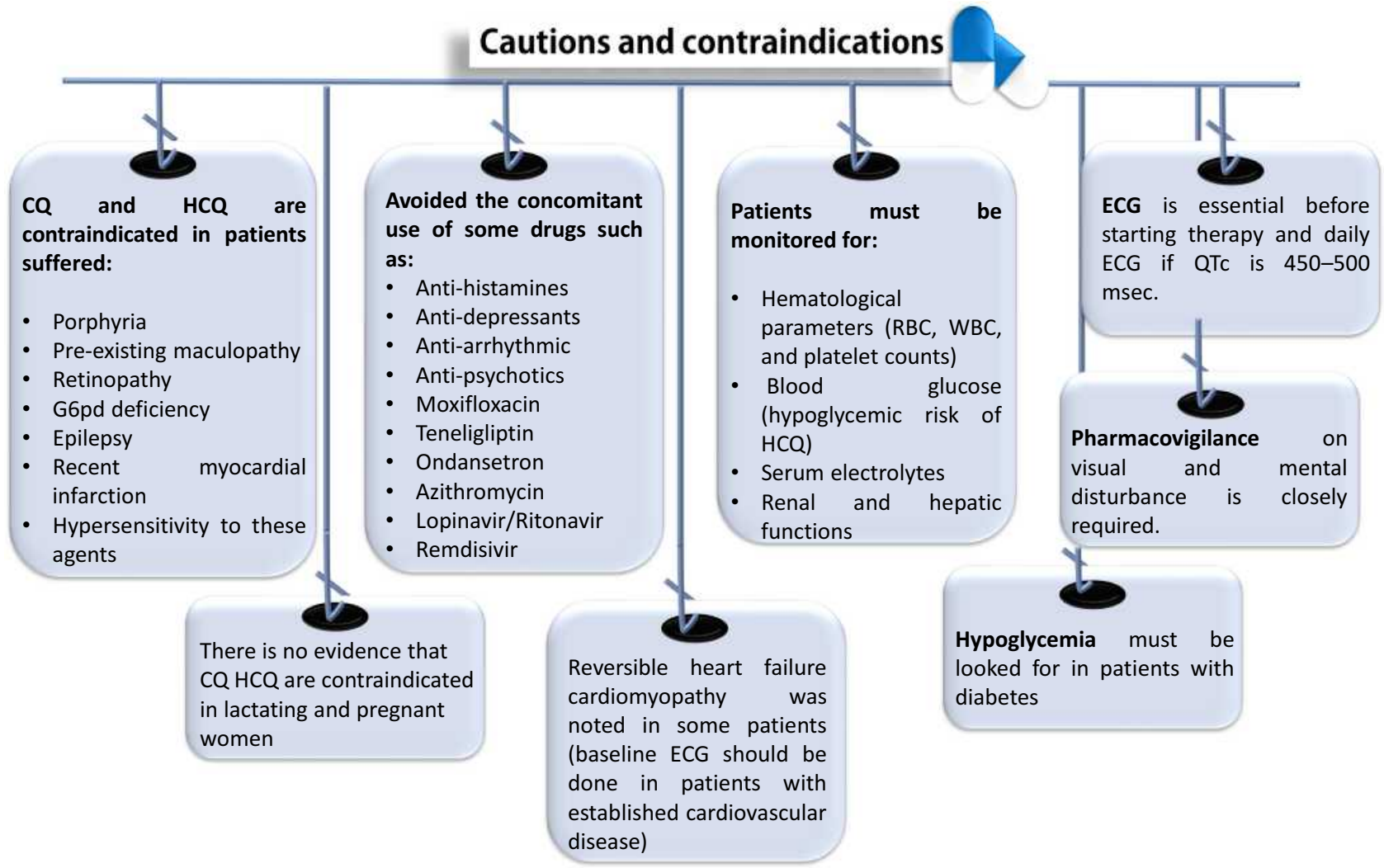

Figure 4 Cautions and contraindications during treatment with chloroquine $(C Q)$ and hydroxychloroquine (HCQ).

regimen with azithromycin. Such patients require close cardiac monitoring as long as they are on the CQ/HCQ regimen. $^{23}$ Besides, CQ/HCQ might decrease blood glucose; therefore, these drugs can be used with caution in patients with diabetes mellitus. A recent study showed that using these drugs during the pandemic contributed to 
Table I The Commonest Drug Interactions and Disease Interactions of the Chloroquine (CQ) and Hydroxychloroquine (HCQ) Regimen

\begin{tabular}{|c|c|c|}
\hline & CQ & HCQ \\
\hline $\begin{array}{l}\text { Drug } \\
\text { interactions }\end{array}$ & $\begin{array}{l}\text { - Hydroxyzine } \\
\text { - Azithromycin } \\
\text { - Ciprofloxacin } \\
\text { - Duloxetine } \\
\text { - HCQ } \\
\text { - Levetiracetam } \\
\text { - Pregabalin } \\
\text { - Mefloquine } \\
\text { - Primaquine } \\
\text { - Albuterol }\end{array}$ & $\begin{array}{l}\text { - Amitriptyline } \\
\text { - Calcium/Vitamin D } \\
\text { - } \text { Duloxetine } \\
\text { - Leflunomide } \\
\text { - Albuterol } \\
\text { - Tramadol }\end{array}$ \\
\hline $\begin{array}{l}\text { Disease } \\
\text { interactions }\end{array}$ & $\begin{array}{l}\text { - Oculotoxicity } \\
\text { - Porphyria } \\
\text { - Arrhythmias } \\
\text { - Bone marrow suppression } \\
\text { - Ototoxicity } \\
\text { - Seizures } \\
\text { - Glucose-6-PD deficiency } \\
\text { - Hepatotoxicity } \\
\text { - Myasthenia gravis } \\
\text { - Psoriasis }\end{array}$ & $\begin{array}{l}\text { - Oculotoxicity } \\
\text { - Porphyria } \\
\text { - Arrhythmias } \\
\text { - Bone marrow suppression } \\
\text { - Ototoxicity } \\
\text { - Seizures } \\
\text { - Glucose-6-PD deficiency } \\
\text { - Hepatotoxicity } \\
\text { - Myasthenia gravis } \\
\text { - Psoriasis } \\
\text { - Diabetes } \\
\text { - Heart disease } \\
\text { - Renal impairment }\end{array}$ \\
\hline
\end{tabular}

hypoglycaemic events. ${ }^{26}$ A summary of the common drug and disease interactions of CQ and HCQ are shown in (Table 1).

\section{Methods of Selecting Studies for This}

\section{Review}

We searched PubMed, SCOPUS, and Web of Science until December 31, 2020, using the keywords "(chloroquine OR hydroxychloroquine) and (COVID-19 OR SARS-CoV-2 OR 2019-nCOV)". Studies were screened for eligibility for this review. Studies meeting the following conditions were reviewed (1) study design: experimental animal studies and prospective clinical trials, (2) study drug: chloroquine and hydroxychloroquine, (3) outcomes: viral inhibition in experimental studies and mortality or time to recovery in clinical trials. Studies that do not satisfy these criteria were excluded from the review. Eligible studies were presented in tables and narratively discussed in the text.

\section{Experimental Studies}

The continuous and rapid spread of the COVID-19 pandemic has led to extensive ongoing efforts worldwide to develop effective and safe therapy. CQ and HCQ in COVID-19 are among the drugs being tested, which were reported on February 4, 2020, to suppress SARS-CoV-2 in vitro. There is considerable in vitro evidence that $\mathrm{CQ}$ and $\mathrm{HCQ}$ are efficient in preventing SARS-CoV-2 vigour. Liu et $\mathrm{al}^{3}$ detected that both drugs have a $50 \%$ cytotoxic concentration (CC50). However, the 50\% maximum efficient concentration was lower for CQ than HCQ (EC50 - the dose at which viral RNA elevation is suppressed by $50 \%$ ) regardless of the multiplicity of infection (MOI - the ratio of virions to host cells). ${ }^{3}$

Wang et $\mathrm{al}^{27}$ found that CQ has in vitro antiviral vigour with an EC50 of $1.13 \mu \mathrm{M}$ and CC50 >100 $\mu \mathrm{M}$ at an MOI of 0.05 and shown that the eclecticism for SARS-CoV-2 is high compared with that for host cells. The study also showed that CQ at a concentration of $0.36 \mathrm{mg} / \mathrm{L}$ decreased viral load by $50 \%$ in vitro using Vero E6 cells. ${ }^{27}$

Yao et $\mathrm{al}^{28}$ also proved the activity of $\mathrm{CQ}$ versus SARS-CoV-2 and detected that CQ was less potent than HCQ in vitro versus SARS-CoV-2 (EC50 of $5.47 \mu \mathrm{M}$ and $0.72 \mu \mathrm{M}$, respectively, $\mathrm{MOI}=0.01)$. Based on physiologically based pharmacokinetic (PBPK) model results, oral HCQ sulfate with a supplying dose of $400 \mathrm{mg}$ twice a day then $200 \mathrm{mg}$ twice a day as a maintenance dose for four days is advised for SARS-CoV-2 infection, and it is three times more potent than CQ phosphate when given $500 \mathrm{mg}$ twice per day for five days in advance. ${ }^{28}$

\section{Clinical Trials on CQ/HCQ Regimen for the Protection Against SARS-CoV-2 Infection}

Although preclinical evidence suggests that CQ and HCQ can inhibit viral replication and might prevent COVID-19, the current evidence does not support their prophylaxis efficacy against SARS-CoV-2 infection. ${ }^{27}$

Expert opinions advised using the $\mathrm{CQ} / \mathrm{HCQ}$ regimen for prophylaxis against SARS-CoV-2 infection, particularly between healthcare laborers who are at higher hazard of infection. ${ }^{29,30}$ However, this opinion was refuted by data from a well-designed randomized controlled trial on 821 participants. Participants were allocated to be administrated with either HCQ or placebo within four days after exposure. The happening of novel symptoms compatible with COVID-19 did not vary markedly among the two groups $(11.8 \%$ versus $14.3 \%$; $\mathrm{P}=0.35) .{ }^{31}$ 


\section{Clinical Experiments on $\mathrm{CQ} / \mathrm{HCQ}$ Regimen for the Therapy of COVID-19}

Recent literature has suggested that $\mathrm{CQ} / \mathrm{HCQ}$ drugs could be used as antiviral drugs to cure COVID-19 infections. ${ }^{24}$ In addition, Iyer et $\mathrm{al}^{32}$ stipulated that the CQ can block the quinone reductase-2, a fundamental agent needed for the sialic acid biosynthesis that SARS-CoV-2 utilizes it as the receptor moieties. A recent small clinical study by Gautret et $\mathrm{al}^{22}$ reported that positive SARS-CoV-2 in nasopharyngeal secretions significantly decreased on day six after inclusion in HCQ-treated COVID-19 patients against patients who received supportive care only. ${ }^{22}$ The CQ elevates $\mathrm{pH}$ in host cell lysosomes and passively affects virus-receptor linking and intervenes with the glycosylation of SARS-CoV-2 receptors. Additionally, it showed a hopeful antiviral influence versus SARS-CoV-2 in vitro and limited the course of the disease and enhanced COVID-19-pneumonia patients. ${ }^{33}$

The first evidence of CQ effectiveness in COVID-19 came from China in February 2020 by the Chinese government. ${ }^{34}$ These data reported that CQ phosphate was given to over 100 patients in China and reduced the duration of illness and significantly improved pneumonia infection and lung imaging. There were no adverse events reported. It seems that combining data from various inprogress trials using a variety of study designs released such findings. A study by Gautret et $\mathrm{al}^{22}$ in France on March 17, 2020, considered as the first clinical trial, was conducted as an open-label non-randomized controlled experiment. $^{22}$ The trial included patients who suffered from SARS-CoV-2 among which 22 of the 36 patients included in the study had symptoms in the upper respiratory tract, eight had symptoms in the lower respiratory tract, while six patients were asymptomatic. ${ }^{22}$ The experimental group (22 patients) was treated with HCQ $200 \mathrm{mg}$ three times per day for ten days, whereas the control group was treated with ordinary care. ${ }^{22}$ Azithromycin was also prescribed for six patients of the treatment group to prevent bacterial superinfection. In this trial, SARS-CoV-2 carriage at day 6 was the primary outcome which was examined by testing nasopharyngeal swabs utilizing PCR of SARS-CoV-2 RNA. ${ }^{22}$

The experiment's outcomes revealed that the experimental group was markedly tested negative for the virus than patients in the control group ( $70 \%$ vs. $12.5 \%$ virologically cured, $P<0.001)$ on day 6 . Furthermore, the results of HCQ and azithromycin combination were astonishing as all patients treated with this combination were negative on day 6. The study proved the efficiency of HCQ and the possible synergistic influence of its combination with azithromycin needs further declaration, as suggested by Gautret et al. ${ }^{22}$

Despite this trial's favourable outcomes, severe limitations have made its results questionable. ${ }^{35}$ First, there was recruitment for an additional six patients but were excluded, and no intention-to-treat analysis was performed due to many reasons that have led to the failure of following-up these patients. ${ }^{35,36}$ Secondly, the researchers added that the sample size was not enough to achieve $85 \%$ power, which required recruiting 48 patients for the required power to be achieved. The overstatement of influence sizes and false-positive outcomes can be expected from the underpowered trial with a sample size of 36 patients. ${ }^{37}$ On the sixth day, the researchers reported that a patient showed negative for the virus but revealed positive on the eighth day, which raised a concern about a trial lacking for long-term and medium follow-up data since the primary outcome is viral PCR status at day $6 .{ }^{37}$ This incidence indicates that long-term data of $\mathrm{CQ} / \mathrm{HCQ}$ effectiveness in the therapy of COVID-19 is necessary. Finally, the trial's allocation bias cannot be denied where there was no randomization for patients to the control and treatment groups. ${ }^{37}$

Another pilot study published on March 25, 2020, by Chen et $\mathrm{al}^{38}$ who evaluated the safety and efficacy of HCQ in the management of patients with COVID-19. A sum of 30 patients diagnosed with COVID-19 was recruited and randomly allocated (1:1) into the treatment and control groups. The test group treated with oral CQ sulfate (400 mg one time a day for five days) based on conventional treatment, while the control group received traditional treatment. ${ }^{38}$ The principal outcome was the negative change rate of COVID-19 nucleic acid in respiratory pharyngeal swab on the seventh day. On day 7, the test group's throat swabs showed negative COVID-19 nucleic acid in 13 patients $(86.7 \%)$, with one case progressed to severe during the treatment. ${ }^{38}$ In comparison to the treatment group, 14 (93.3\%) subjects in the control group $(P>0.05)$ also tested negative. The average period between virus nucleic acid negative maintenance and patients' hospitalization in the test and control groups was 4 (1-9) days and 2 (1-4) days, respectively ( $\mathrm{U}=83.5, P>0.05) .{ }^{38}$ In terms of safety, abnormal liver function and transient diarrhea in the experimental and the control groups subjects were noticed in $4(26.7 \%)$ and $3(20 \%)$ cases, respectively $(P>0.05)$. 
The small sample size in this study has made a general conclusion that the prediction of typical COVID-19 patients is perfect. $^{38}$

Following that, an extensive argument was raised against Gautret et $\mathrm{al}^{22}$ study by Kim et al. ${ }^{39}$ It was reported that there was a rush in judgment of the study due to the pressing requirement for efficient therapy for SARS-CoV -2 . The clinical trial's limitations were discussed, such as using an invalidated replacement endpoint, deficiency of blinding or randomization, and including the small sample size. Another study highlighted methodological flaws that were considered to impact the validity of the findings. ${ }^{40}$

Despite the limitations in the first clinical trial, its promising results ended up advising the usage of $\mathrm{CQ}$ / HCQ in the management of COVID-19 officially by guidelines. The National Health Commission published the recommendation of treatment COVID-19 by CQ, China, published in mid-February 2020, indicating that $500 \mathrm{mg}$ CQ phosphate (equivalent to $300 \mathrm{mg} \mathrm{CQ}$ ) twice per day for ten days is recommended for patients with COVID-19. ${ }^{41}$ On March 17, 2020, other recommendations published by the L. Spallanzani National Institute for Infectious Disease in Italy, in which the combination of CQ (500 mg CQ per day) or HCQ (200-500 mg HCQ per day) with a different antiviral drug is indicated for COVID-19. ${ }^{42}$

A pharmacokinetic study in France aimed to optimize HCQ dosing in the intensive care unit (ICU) of COVID-19 patients was carried out by Perinel et al. ${ }^{43}$ The study recruited 13 patients in ICU who were treated by HCQ at a dose of $200 \mathrm{mg}$ twice per day. The mean age of patients was 68 years, $31 \%$ with moderate or severe renal failure, and $46 \%$ were obese. ${ }^{43}$ The study demonstrated that the dosing regimen of $200 \mathrm{mg}$ thrice a day is inappropriate to reach a supposed target blood level of 1$2 \mathrm{mg} / \mathrm{L}$ in this population. According to data from patients with rheumatoid arthritis and the 161 blood levels registered, the proposed dosing regimen delivers a dose of $800 \mathrm{mg}$ once per day on the first day, then $200 \mathrm{mg}$ twice per day for seven days. ${ }^{43}$

The efficacy of combining azithromycin and HCQ was also evaluated by an uncontrolled non-comparative observational study carried out by Gautret et $\mathrm{al}^{22}$ in 80 patients diagnosed with a relatively mild infection of COVID-19. Six days were set as the minimum follow-up period. There was a clinically marked amelioration in all patients, except for one patient aged 86 years who died, and another patient (74-year-old) was still in the ICU. The viral load of nasopharyngeal samples rapidly decreased. Of these samples, $83 \%$ of the patients were tested negative on the seventh day, while on the eight's day, $93 \%$ were negative. $^{22}$ On day 5 of the treatment, respiratory samples' viral cultures were found negative in $97.5 \%$ of the patients. ${ }^{22}$ Therefore, patients were quickly got out of the infectious disease unit with five days as an average length of stay. Although the number of patients was just 80 and the severity of the illness was mild, the study reflected an excellent picture of the combination of azithromycin and $\mathrm{HCQ}^{22}$

Regarding the optimal dose of HCQ in COVID-19 patients, Garcia-Cremades et $\mathrm{al}^{44}$ tested the safe and effective dosage of HCQ for COVID-19 treatment. It was predicted that doses of over $400 \mathrm{mg}$ twice a day of HCQ for $\geq 5$ days reduced viral loads quickly, shortening the treatment course, decreasing the number of patients with detectable SARS-CoV-2 infection. ${ }^{44}$ In contrast, increasing the dose of HCQ to over $600 \mathrm{mg}$ twice a day has more probability of prolonging QTc intervals. ${ }^{44}$ In recent study from Belgium, Catteau et $\mathrm{al}^{45}$ have shown that the low dose HCQ monotherapy has reduced mortality rate compared with the non-HCQ treated patients. ${ }^{45}$

A study from South Korea by Lee et $\mathrm{al}^{46}$ investigated the effectiveness of post-exposure prophylaxis after a significant exposure of COVID-19 in a long-term care hospital using HCQ (400 mg orally daily till the end of 14 days of quarantine) in 211 persons containing 22 healthcare workers and 189 patients, with negative PCR checks for COVID-19. ${ }^{46}$ After completing the post-exposure prophylaxis period by 184 patients and 21 care-workers without any severe effects, all PCR tests were negative at the ending of the 14 days of quarantine. ${ }^{46}$ The shortage of control groups in the study and having other 29 hospital staff who tested negative after the 14 days of quarantine although they did not receive post-exposure prophylaxis (Although being classified low-risk exposure) are considered essential limitations in the study. ${ }^{46}$ In a study highlighted COVID-19 and immunomodulation in inflammatory bowel diseases (IBD), Neurath ${ }^{47}$ mentioned that there is a possibility for drug-drug interactions between HCQ or IBD therapies. The risk of interaction is potentially increased by combination of medication with HCQ and infliximab/adalimumab for nerve harm. ${ }^{47}$

However, there is no evidence to discontinue IBDspecific medications in COVID-19 patients cured with such drugs. The favourable effect of HCQ and azithromycin combination on the clinical results and viral loads of 
patients infected with COVID-19 has led to implementing the regimen by clinicians worldwide. ${ }^{48}$ On the other hand, both drugs have been independently revealed to influence the electrical system of the heart, causing QT-interval elongation, drug-induced torsades de pointes, and drugstimulated sudden cardiac death. ${ }^{48}$

In this context, an American study carried out by Chorin et $\mathrm{al}^{49}$ examined the QT-interval in 84 patients with COVID-19 cured with a combination of HCQ (400 $\mathrm{mg}$ daily on day one, then $200 \mathrm{mg}$ daily from day 2 to 5) and azithromycin (500 $\mathrm{mg}$ per day for five days). After $4.3 \pm 1.7$ days as an average time for exposure to HCQ/azithromycin, ECG was followed up. ${ }^{49}$ It was found that the QTc markedly extended. In a group of nine (11\%) of those patients, there was a severe prolongation of the QTc to $>500 \mathrm{~ms}$, which is a marker of a high danger of sudden cardiac death caused by malignant arrhythmia. ${ }^{49}$ Out of the group of nine patients, five patients had a normal QTc. It was suggested that regular evaluation for QTc must be implemented by patients with COVID-19 who are cured with a combination of $\mathrm{HCQ}$ /azithromycin combination, especially those who have comorbidities or/ and with other QT-prolonging medications. ${ }^{49}$

A randomized clinical experiment by Borba et $\mathrm{al}^{50}$ from Brazil compared the effect of high doses $(600 \mathrm{mg}$ twice per day for ten days) against small doses (450 mg twice a day on day one and OD for four days) of CQ diphosphate as adjunctive therapy for 81 adult patients treated with SARS-CoV-2 infection. ${ }^{50}$ Forty patients received low doses, while 41 received high doses. In the small dose group, $15.0 \%$ (6 out of 40) of patients died on day 13 days compared with $39 \%$ of the high-dose group (16 of the 41 patients). Regarding safety, 4 of 36 patients (11.1\%) receiving low-dose experienced prolongation of QTc interval compared with 7 of 37 (18.9\%) patients receiving the high-dose.$^{50}$ Besides, ventricular tachycardia was developed in 2 patients (2.7\%) in the high-dose group. As a result of these findings, the trial was stopped. It was inferred that the high dosage of CQ must not be advised for adversely ill patients with COVID-19. ${ }^{50}$

Patients with systemic lupus erythematosus (SLE) were a population of interest for Mathian et al. ${ }^{51}$ SARS-CoV-2 represents a source of concern for the management of patients with SLE. In patients with SLE, the use of immunosuppressive drugs, the intrinsic perturbations of the immune response, and the potential presence of organ damage associated with their disease make those patients at higher risk of severe infections. Currently, and as a part of SLE treatment, HCQ is a standard long-term drug for SLE. $^{52}$

HCQ also has antiviral activity in COVID-19, and its therapeutic or even prophylactic activity for COVID-19 was proved by preliminary clinical trials. Mathian et $\mathrm{al}^{51}$ examined the clinical observations of COVID-19 in a series of 17 patients with SLE receiving long-term treatment of HCQ (median of 7.5 years) and with obesity and chronic kidney disease as comorbidities. ${ }^{51}$ Although this study gave an initial clinical view of the infection course in patients with SLE cured with HCQ, it did not conclude the severity and incidence rate of COVID-19 in SLE. Moreover, it was also shown that HCQ does not protect against COVID-19, at least its negative practice, in patients with SLE. ${ }^{51}$

On the other hand, strong evidence from a welldesigned randomized controlled trial (RCT) does not advocate the usage of CQ/HCQ regimens in COVID-19 patients. Data from the UK's recovery trial, the world's largest COVID-19 clinical trial to date, by Horby and Landray $^{53}$ showed that HCQ did not reduce the 28-day mortality rate among COVID-19 patients compared to the standard of care. ${ }^{53}$ While these outcomes were questioned by several experts owing to the relatively higher loading dose.

On the first day of the study ( $2400 \mathrm{mg}$ in 24 hours), similar findings were reached by the WHO's solidarity trial in several countries worldwide. On June 5, 2020, the WHO announced that based on an interim analysis of the trial data, HCQ did not reduce the mortality compared to the standard of care. ${ }^{54}$ The characteristics of the in vitro studies on SARS-CoV-2 and clinical trials studying the efficacy of CQ and HCQ in COVID-19 patients are illustrated in Table 2.

\section{Past Experiences, Current Situations, and Future Directions}

Based on the review of the existing literature, the $\mathrm{CQ} /$ HCQ regimen gained worldwide attention. It showed a promise in the preclinical experiments and some clinical studies during the early months of the pandemic. Nonetheless, the usage of the CQ/HCQ regimen in treating COVID-19 has been challenged by the recent data from well-designed RCTs. The CQ and HCQ are widely used for the first-line of treatment against the malarial parasite in most endemic Asia and African countries. ${ }^{63}$ Besides malaria treatment, CQ is utilized in rheumatoid arthritis, 
Table 2 Characteristics of the in vitro Investigations on SARS-CoV-2 and Clinical Trials Studying the Efficacy of Chloroquine and Hydroxychloroquine in COVID-19 Patients

\begin{tabular}{|c|c|c|c|}
\hline $\begin{array}{l}\text { Reference } \\
\text { and Country }\end{array}$ & $\begin{array}{l}\text { Population } \\
\text { (n Patients) }\end{array}$ & $\begin{array}{l}\text { Intervention and Comparison } \\
\text { Groups }\end{array}$ & Primary Outcomes \\
\hline China $^{28}$ & $\begin{array}{l}\text { in vitro study with SARS-CoV-2-infected } \\
\text { Vero cells }\end{array}$ & $\begin{array}{l}\text { Infected Vero cells were treated with CQ } \\
\text { or HCQ at } 0.032,0.16,0.80,4,20 \text {, or } \\
100 \mu \mathrm{M} \text { for } 24 \text { or } 48 \mathrm{~h} \text {. }\end{array}$ & $\begin{array}{l}\text { - } \mathrm{CQ} \text { and } \mathrm{HCQ} \text { decreased viral replication } \\
\text { in a concentration-dependent manner. } \\
\text { - } \mathrm{EC}_{50} \text { values for } \mathrm{CQ} \text { were } 23.90 \text { and } 5.47 \\
\mu \mathrm{M} \text { at } 24 \text { and } 48 \mathrm{~h} \text {, respectively. } \\
\text { - } \mathrm{EC}_{50} \text { values for } \mathrm{HCQ} \text { were } 6.14 \text { and } \\
0.72 \mu \mathrm{M} \text { at } 24 \text { and } 48 \mathrm{~h} \text {, respectively. }\end{array}$ \\
\hline China $^{28}$ & in vitro study with Vero cells & $\begin{array}{l}\text { Vero cells were pre-treated CQ or HCQ } \\
\text { at } 0.032,0.16,0.80,4,20 \text {, or } 100 \mu \mathrm{M} \text { for } \\
\text { two } \mathrm{h} \text { and were then infected with SARS- } \\
\text { CoV-2 and incubated for } 24 \text { or } 48 \mathrm{~h} \text {. }\end{array}$ & $\begin{array}{l}\text { - } \mathrm{HCQ} \text { showed a higher in vitro antiviral } \\
\text { influence in comparison with CQ. } \\
\text { - The } \mathrm{EC}_{50} \text { values for } \mathrm{CQ} \text { were greater } \\
\text { than } 100 \text { and } 18.0 \mathrm{I} \mu \mathrm{M} \text { at } 24 \text { and } 48 \mathrm{~h} \text {, } \\
\text { respectively. } \\
\text { - } \mathrm{EC}_{50} \text { values for } \mathrm{HCQ} \text { were } 6.25 \text { and } \\
5.85 \mu \mathrm{M} \text { at } 24 \text { and } 48 \mathrm{~h} \text {, respectively. }\end{array}$ \\
\hline China $^{3}$ & $\begin{array}{l}\text { in vitro study with African green monkey } \\
\text { kidney VeroE6 cells }\end{array}$ & $\begin{array}{l}\text { SARS-CoV-2 infected cells at four } \\
\text { different multiplicities of infection (MOI) } \\
\text { and treated with CQ or HCQ up to } 50 \\
\mu \mathrm{M} \text { for } 48 \mathrm{~h}\end{array}$ & $\begin{array}{l}\text { - } \mathrm{CC}_{50} \text { values of } \mathrm{CQ} \text { and } \mathrm{HCQ} \text { were } 273 \\
\text { and } 250 \mu \mathrm{M} \text {, respectively, which are not } \\
\text { significantly different. } \\
\text { - At all } \mathrm{MOI}(0.0 \mathrm{I}, 0.02,0.2 \text {, and } 0.8), \mathrm{EC}_{50} \\
\text { for } \mathrm{HCQ}(4.5 \mathrm{I}, 4.06,17.3 \mathrm{I} \text {, and } 12.96 \\
\mu \mathrm{M}) \text { was higher than that of } \mathrm{CQ}(2.7 \mathrm{I} \text {, } \\
\text { 3.8I, 7.I4, and } 7.36 \mu \mathrm{M}) \text {. } \\
\text { - Statistically, the variations in } \mathrm{EC}_{50} \text { values } \\
\text { were significant at } \mathrm{MOI} \text { of } 0.0 \mathrm{I}(P<0.05) \\
\text { and } 0.2(P<0.00 \mathrm{I}) \text {. }\end{array}$ \\
\hline China $^{27}$ & in vitro study with Vero E6 cells. & $\begin{array}{l}\text { Cells were infected with SARS-CoV- } 2 \text { at } \\
\text { MOI of } 0.05 \text { in the presence of different } \\
\text { concentrations of CQ, penciclovir, } \\
\text { ribavirin, nafamostat, nitazoxanide, } \\
\text { remdesivir, favipiravir and chloroquine. }\end{array}$ & $\begin{array}{l}\text { - } \mathrm{EC}_{50}, \mathrm{SI} \text { index, and } \mathrm{CC}_{50} \text { values for } \mathrm{CQ} \\
\text { were I.I } 3 \mu \mathrm{M},>100 \mu \mathrm{M} \text {, and } 88.5 \text {. } \\
\text { - These values were higher for for ribavirin } \\
\left(\mathrm{EC}_{50}=\mathrm{II} \mu \mu \mathrm{M}, \mathrm{CC}_{50}>400 \mu \mathrm{M} \text {, and } \mathrm{SI}>\right. \\
\text { 3.65), penciclovir }\left(\mathrm{EC}_{50}=96.0 \mu \mathrm{M}, \mathrm{CC}_{50}\right. \\
>400 \mu \mathrm{M}, \mathrm{SI}>4.17) \text { and favipiravir }\left(\mathrm{EC}_{50}\right. \\
\left.=61.9 \mu \mathrm{M}, \mathrm{CC}_{50}>400 \mu \mathrm{M}, \mathrm{SI}>6.46\right) \text {, } \\
\text { nafamostat }\left(\mathrm{EC}_{50}=22.50 \mu \mathrm{M}, \mathrm{CC}_{50}>100\right. \\
\mu \mathrm{M}, \mathrm{SI}>4.44) \text {, and was comparable to } \\
\text { nitazoxanide }\left(\mathrm{EC}_{50}=2.12 \mu \mathrm{M} ; \mathrm{CC}_{50}>\right. \\
35.53 \mu \mathrm{M} ; \mathrm{SI}>16.76) \text { and remdesivir } \\
\left(\mathrm{EC}_{50}=0.77 \mu \mathrm{M} ; \mathrm{CC}_{50}>100 \mu \mathrm{M} ; \mathrm{SI}>\right. \\
\mathrm{I29.87)} \text { for } \mathrm{EC}_{50} \text {. }\end{array}$ \\
\hline France $^{22}$ & $\begin{array}{l}\text { Age }>12 \text { years and positive for SARS- } \\
\text { CoV-2. Patients with HCQ or CQ allergy } \\
\text { were excluded or had another } \\
\text { recognized contraindication to cure with } \\
\text { the drug. Pregnant and breastfeeding } \\
\text { patients were excluded. }\end{array}$ & $\begin{array}{l}\text { Oral HCQ } 200 \mathrm{mg} \text { TD } \times \text { ten days }(n=20) \text {. } \\
\text { Symptomatic treatment and AZT }(n=6 \text {; } \\
500 \mathrm{mg} / \mathrm{d} \text { on day I then } 250 \mathrm{mg} / \mathrm{d} \text { for } \\
\text { next } 4 \text { days) with HCQ. } \\
\text { Patients }(\mathrm{n}=16) \text { who rejected the cure or } \\
\text { had relegation criteria, served as } \\
\text { controls. }\end{array}$ & $\begin{array}{l}\text { - Control patients were younger than } \mathrm{HCQ} \text { - } \\
\text { treated patients ( } 37.3 \text { years vs } 5 \mathrm{I} .2 \text { years). } \\
\text { - At sixth day post-inclusion, } 70 \% \text { of } \mathrm{HCQ} \text { - } \\
\text { cured patients were negative compared } \\
\text { with } \mathrm{I} 2.5 \% \text { in the control group ( } \mathrm{p}=0.00 \mathrm{I} \text { ). } \\
\text { - At day six post-inclusion, } 100 \% \text { of patients } \\
\text { treated with combination of } \mathrm{HCQ} \text { and } \mathrm{AZT} \\
\text { were negative compared with } 57.1 \% \text { in } \\
\text { patients cured with } \mathrm{HCQ} \text { only, and } \mathrm{I} 2.5 \% \text { in } \\
\text { the control group ( } \mathrm{p}<0.00 \mathrm{I} \text { ). }\end{array}$ \\
\hline
\end{tabular}

(Continued) 
Table 2 (Continued).

\begin{tabular}{|c|c|c|c|}
\hline $\begin{array}{l}\text { Reference } \\
\text { and Country }\end{array}$ & $\begin{array}{l}\text { Population } \\
\text { (n Patients) }\end{array}$ & $\begin{array}{l}\text { Intervention and Comparison } \\
\text { Groups }\end{array}$ & Primary Outcomes \\
\hline China $^{38}$ & $\begin{array}{l}\text { Confirmed COVID-19 patients. Thirty } \\
\text { patients were randomly grouped into } \\
\text { treatment and control groups. }\end{array}$ & $\begin{array}{l}\text { Oral HCQ sulfate } 400 \mathrm{mg} \text { OD } \times 5 \text { days } \\
(n=15) \text {. } \\
\text { No HCQ was provided to Patients } \\
(n=15) .\end{array}$ & 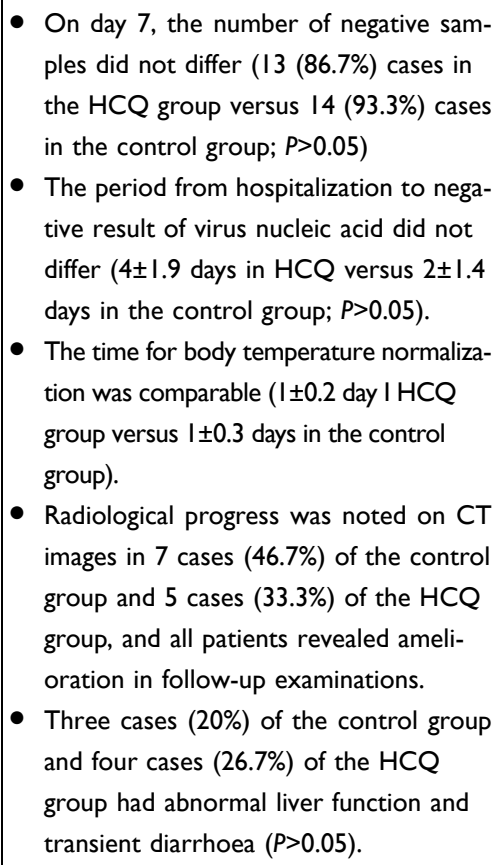 \\
\hline South Korea ${ }^{46}$ & $\begin{array}{l}\text { COVID-19 exposed individuals ( } 211 \\
\text { containing } 22 \text { careworkers and } 189 \\
\text { patients) with negative PCR tests for } \\
\text { COVID-19 in a long-term care hospital in } \\
\text { Korea. Four patients and one coworker } \\
\text { were not finally completed. }\end{array}$ & $\begin{array}{l}\text { COVID-19 exposed individuals were } \\
\text { administered } \mathrm{HCQ} \text { at } 400 \mathrm{mg} \text { OD } \times 14 \\
\text { days during the quarantine. } \\
\text { No control groups. }\end{array}$ & $\begin{array}{l}\text { - At the ending of two weeks of quarantine, } \\
\text { all follow-up PCR tests were negative. } \\
\text { - A sum of } 32 \text { individuals (15.6\%) men- } \\
\text { tioned one or more symptoms through } \\
\text { post-exposure prophylaxis. } \\
\text { - The most common symptoms were skin } \\
\text { rash ( } 4.3 \%) \text {, loose stool or diarrhoea } \\
\text { (9\%), bradycardia ( } 0.95 \%) \text {, and gastroin- } \\
\text { testinal upset ( } 0.95 \%) \text {. Post-exposure } \\
\text { prophylaxis was stopped in } 5 \text { patients } \\
\text { (2.7\%) because of the requirement for } \\
\text { fasting (I), bradycardia (2), and gastro- } \\
\text { intestinal upset (2). }\end{array}$ \\
\hline Netherlands ${ }^{55}$ & $\begin{array}{l}\text { Patients }(n=95) \text { were aged } 18 \text { years or } \\
\text { older and suspected of having COVID-19 } \\
\text { disease. }\end{array}$ & $\begin{array}{l}\mathrm{CQ} \text { was a loading dose of } 600 \mathrm{mg} \\
\text { followed by } 300 \mathrm{mg} B D \text { (starting } 12 \\
\mathrm{~h} \text { after the loading dose), for the next } \\
\text { four days }\end{array}$ & $\begin{array}{l}\text { - CQ treatment in patients with COVID-19 } \\
\text { markedly extended the QTc interval by } \\
\text { 34-35 ms; } 23 \% \text { of the patients had a QTc } \\
\text { interval exceeding } 500 \mathrm{~ms} \text {. Statistically } \\
\text { marked influences were detected on QRS } \\
\text { interval (mean difference } 6 \mathrm{~ms} \text { ), PR inter- } \\
\text { val (mean difference } 8 \mathrm{~ms} \text { ), and heart rate } \\
\text { (mean difference }-10 \mathrm{bpm} \text { ). }\end{array}$ \\
\hline
\end{tabular}

(Continued) 
Table 2 (Continued).

\begin{tabular}{|c|c|c|c|}
\hline $\begin{array}{l}\text { Reference } \\
\text { and Country }\end{array}$ & $\begin{array}{l}\text { Population } \\
\text { (n Patients) }\end{array}$ & $\begin{array}{l}\text { Intervention and Comparison } \\
\text { Groups }\end{array}$ & Primary Outcomes \\
\hline Netherlands ${ }^{23}$ & $\begin{array}{l}\text { A retrospective investigation of } 25 \mathrm{I} \\
\text { patients having COVID- } 19 .\end{array}$ & $\begin{array}{l}\text { HCQ was orally administrated at } 400 \mathrm{mg} \\
\text { BD for one day (loading dose) then } \\
200 \mathrm{mg} \text { BD for four days. AZT was orally } \\
\text { administrated for five days at a dose of } \\
500 \mathrm{mg} \text { OD. }\end{array}$ & $\begin{array}{l}\text { - The QTc interval extended from } \\
\text { a baseline of } 439 \pm 29 \mathrm{~ms} \text { to a maximum } \\
\text { value of } 473 \pm 36 \mathrm{~ms}(P<.00 \mathrm{I}) \text {, which } \\
\text { happen on day } 4.1 \pm 2 \text { of treatment. } \\
\text { - Extreme novel QTc interval extension to } \\
>500 \mathrm{~ms} \text { revealed in } 23 \% \text { of the patients. } \\
\text { - One patient showed polymorphic ventri- } \\
\text { cular tachycardia. }\end{array}$ \\
\hline USA $^{56}$ & $\begin{array}{l}\text { A retrospective investigation of } 1376 \\
\text { patients having COVID-19. }\end{array}$ & $\begin{array}{l}\mathrm{HCQ}(\mathrm{n}=8 \mathrm{II}) \text { was provided at } 600 \mathrm{mg} \\
\mathrm{BD} \text { on day I, followed by } 400 \mathrm{mg} / \mathrm{d} \text { for } 4 \\
\text { next days. } \\
\text { Control group patients were less } \\
\text { adversely ill at baseline than those with } \\
\mathrm{HCQ} \text {-treated patients ( } \mathrm{n}=565 \text {; the ratio } \\
\text { of the partial pressure of arterial oxygen } \\
\text { to the fraction of inspired oxygen, } 223 \mathrm{vs} \\
360 \text { ). }\end{array}$ & $\begin{array}{l}\text { - HCQ use was not accompanied with } \\
\text { a markedly lower or higher hazard of } \\
\text { death or intubation (hazard ratio, I.04; } \\
95 \% \mathrm{Cl}, 0.82 \text { to } 1.32 \text { ). }\end{array}$ \\
\hline$U_{S A}^{57}$ & $\begin{array}{l}\text { A retrospective investigation of } 368 \\
\text { patients diagnosed with COVID-19. }\end{array}$ & $\begin{array}{l}\mathrm{HCQ}(\mathrm{n}=97) \text { alone and HCQ + AZT ( } \\
=113) \text { in combination. } \\
\text { In the control group }(n=158) \text {, no HCQ } \\
\text { was provided. }\end{array}$ & $\begin{array}{l}\text { - The hazard of death from any reason } \\
\text { was elevated in the } \mathrm{HCQ} \text { group } \\
\text { (adjusted hazard ratio, } 2.61 ; 95 \% \mathrm{Cl}, \mathrm{I} .10 \\
\text { to } 6.17 ; \mathrm{P}=0.03 \text { ). } \\
\text { - The risk of death was similar in the } \\
\mathrm{HCQ}+\mathrm{AZ} \text { group (adjusted hazard ratio, } \\
\text { I.I4; } 95 \% \mathrm{Cl}, 0.56 \text { to } 2.32 ; \mathrm{P}=0.72 \text { ). } \\
\text { - The hazard of ventilation was compar- } \\
\text { able in the } \mathrm{HCQ} \text { group (adjusted } \\
\text { hazard ratio, I.43; } 95 \% \mathrm{Cl}, 0.53 \text { to } 3.79 \text {; } \\
\mathrm{P}=0.48 \text { ) and the } \mathrm{HC}+\mathrm{AZ} \text { group (adjusted } \\
\text { hazard ratio, } 0.43 ; 95 \% \mathrm{Cl}, 0.16 \text { to I.I2; } \\
\mathrm{P}=0.09 \text { ). }\end{array}$ \\
\hline France $^{58}$ & $\begin{array}{l}\text { A retrospective investigation of } 18 \mathrm{I} \\
\text { patients having COVID-19 and requiring } \\
\text { oxygen } \geq 2 \mathrm{~L} / \mathrm{min} \text {. }\end{array}$ & $\begin{array}{l}\mathrm{HCQ}(\mathrm{n}=84) 600 \mathrm{mg} / \mathrm{d} \text { for } 7 \text { day } \\
\text { In control }(\mathrm{n}=97), \text { no HCQ was } \\
\text { provided. }\end{array}$ & $\begin{array}{l}\text { - } 20.2 \% \text { of the patients in the HCQ group } \\
\text { were died within seven days or moved } \\
\text { to the ICU vs } 22.1 \% \text { in the no-HCQ } \\
\text { group ( } 16 \text { vs } 2 I \text { events, the relative } \\
\text { hazard of } 0.91,95 \% \mathrm{Cl} 0.47-1.80 \text { ) in the } \\
\mathrm{HCQ} \text { group. } \\
\text { - The death of } 2.8 \% \text { of the patients was } \\
\text { within seven days vs } 4.6 \% \text { in the no- } \\
\mathrm{HCQ} \text { group (three vs four events, the } \\
\text { relative risk of } 0.6 \mathrm{I}, 95 \% \mathrm{Cl} 0.13-2.89 \text { ). } \\
27.4 \% \text { in the } \mathrm{HCQ} \text { group versus } 24.1 \% \text { in } \\
\text { control group patients developed acute } \\
\text { respiratory distress syndrome within } \\
\text { seven days ( } 24 \text { vs } 23 \text { events, relative risk } \\
\text { of I.I4, } 95 \% \mathrm{Cl} 0.65-2.00 \text { ). } \\
8 \text { patients receiving } \mathrm{HCQ} \text { (9.5\%) } \\
\text { revealed electrocardiogram modifica- } \\
\text { tions requesting } \mathrm{HCQ} \text { stop. }\end{array}$ \\
\hline
\end{tabular}

(Continued) 
Table 2 (Continued).

\begin{tabular}{|c|c|c|c|}
\hline $\begin{array}{l}\text { Reference } \\
\text { and Country }\end{array}$ & $\begin{array}{l}\text { Population } \\
\text { (n Patients) }\end{array}$ & $\begin{array}{l}\text { Intervention and Comparison } \\
\text { Groups }\end{array}$ & Primary Outcomes \\
\hline USA $^{59}$ & $\begin{array}{l}\text { A retrospective investigation of } 18 \mathrm{I} \\
\text { patients having COVID- } 19 .\end{array}$ & $\begin{array}{l}\mathrm{HCQ} \text { at } 200-600 \mathrm{mg} O D / \mathrm{BD}(\mathrm{n}=27 \mathrm{I}) \\
\text { alone; } \\
\mathrm{HCQ}+\mathrm{AZT}(\mathrm{n}=735) \text { in combination; } \\
\mathrm{AZT} 200-500 \mathrm{mg} \text { once/OD/BD }(\mathrm{n}= \\
2 \mathrm{II}) \text {, and no drug }(\mathrm{n}=22 \mathrm{I})\end{array}$ & 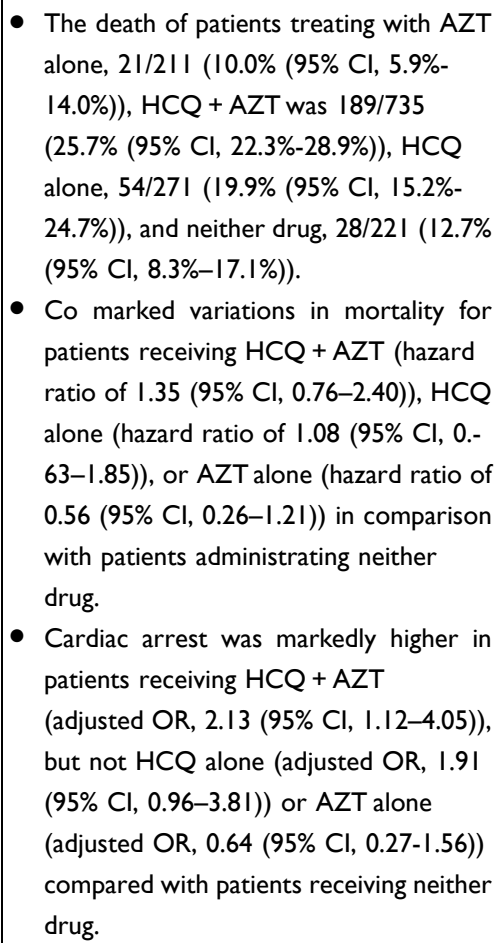 \\
\hline China $^{60}$ & $\begin{array}{l}\text { A retrospective investigation of } 181 \\
\text { patients having COVID-19 and treated } \\
\text { with } \mathrm{HCQ} \text {. }\end{array}$ & $\begin{array}{l}\text { HCQ } 400 \mathrm{mg} / \mathrm{d}(200 \mathrm{mg} \mathrm{BD}) \text { for } 7-10 \\
\text { days }(n=48) . \\
\text { In the control group ( } \mathrm{n}=520) \text {, no HCQ } \\
\text { was provided. }\end{array}$ & $\begin{array}{l}\text { - Mortalities reduced in HCQ group } \\
(18.8 \%(9 / 48) \text { versus } 45.8 \%(238 / 520) \text { in } \\
\text { control group }(\mathrm{p}<0.00 \mathrm{I})) \text {. } \\
\text { - The time of hospitalization before } \\
\text { patient death was } \mathrm{I} 5(\mid 0-2 \mathrm{I}) \text { days for } \\
\text { the } \mathrm{HCQ} \text { group versus } 8(4-14) \text { days for } \\
\text { control groups ( } \mathrm{p}<0.05) \text {. } \\
\text { - The level of inflammatory cytokine IL-6 } \\
\text { markedly decreased from } 22.2(8.3-- \\
\mathrm{II} 8.9) \mathrm{pg} / \mathrm{mL} \text { to } 5.2(3.0-23.4) \mathrm{pg} / \mathrm{ml} \\
\text { ( } \mathrm{p}<0.05) \text { in the } \mathrm{HCQ} \text { group, but there is } \\
\text { no alteration in the control group. }\end{array}$ \\
\hline $\begin{array}{l}\text { Recovery trial } \\
\text { UK }^{61}\end{array}$ & $\begin{array}{l}\text { An ongoing randomized controlled trial } \\
\text { of more than } 11,000 \text { COVID-19 patients } \\
\text { to date }\end{array}$ & $\begin{array}{l}\mathrm{HCQ}(200 \mathrm{mg} \text { tablet containing } 155 \mathrm{mg} \\
\text { base equivalent) received a loading dose } \\
\text { of four tablets }(800 \mathrm{mg}) \text { at zero and six } \\
\text { hours, then two tablets }(400 \mathrm{mg}) \text { starting } \\
\text { at twelve hours after the initial dose and } \\
\text { then every twelve hours for the next nine } \\
\text { days or until discharge. }\end{array}$ & $\begin{array}{l}\text { - 28-day mortality was } 26.8 \% \text { and } 25 \% \text { in } \\
\text { the HCQ and standard of care groups. } \\
\text { - HCQ treatment was markedly accompa- } \\
\text { nied with an elevated length of hospital } \\
\text { stay and elevated hazard of developing to } \\
\text { death. }\end{array}$ \\
\hline $\begin{array}{l}\text { Solidarity } \\
\text { trial }^{54}\end{array}$ & $\begin{array}{l}\text { An ongoing randomized controlled trial } \\
\text { of more than } 5,000 \text { COVID-19 patients } \\
\text { to date }\end{array}$ & $\begin{array}{l}\mathrm{HCQ} \\
\text { Standard of care }\end{array}$ & $\begin{array}{l}\text { - Not Available; Details were not } \\
\text { published. }\end{array}$ \\
\hline
\end{tabular}


Table 2 (Continued).

\begin{tabular}{|c|c|c|c|}
\hline $\begin{array}{l}\text { Reference } \\
\text { and Country }\end{array}$ & $\begin{array}{l}\text { Population } \\
\text { (n Patients) }\end{array}$ & $\begin{array}{l}\text { Intervention and Comparison } \\
\text { Groups }\end{array}$ & Primary Outcomes \\
\hline $\begin{array}{l}\text { US and } \\
\text { Canada }\end{array}$ & $\begin{array}{l}\text { An internet-based randomized controlled } \\
\text { trial in non-hospitalized patients in the US } \\
\text { and Canada }\end{array}$ & $\begin{array}{l}\mathrm{HCQ}(800 \mathrm{mg} \text { once, followed by } 600 \mathrm{mg} \\
\text { in } 6 \text { to } 8 \text { hours, then } 600 \mathrm{mg} \text { daily for } 4 \\
\text { more days) } \\
\text { Placebo }\end{array}$ & $\begin{array}{l}\text { - Symptom severity did not significantly } \\
\text { differ over } 14 \text { days ( }-0.27 \text { points }(95 \% \\
\mathrm{Cl},-0.6 \mathrm{I} \text { to } 0.07 \text { points); } \mathrm{P}=0.1 \mathrm{I} 7) \text {. } \\
\text { - At } \mathrm{I} 4 \text { days, } 24 \% \text { of the participants } \\
\text { receiving } \mathrm{HCQ} \text { had ongoing symptoms } \\
\text { compared with } 30 \% \text { receiving placebo } \\
\text { ( } \mathrm{P}=0.2 \mathrm{I} \text { ). } \\
\text { - Medication adverse effects occurred in } \\
43 \% \text { of } \mathrm{HCQ} \text { group compared to } 22 \% \\
\text { in the placebo group }(\mathrm{P}<0.00 \mathrm{I}) \text {. }\end{array}$ \\
\hline
\end{tabular}

Abbreviations: $\mathrm{HCQ}$, hydroxychloroquine; $\mathrm{CQ}$, chloroquine; $\mathrm{OD}$, one a day; $\mathrm{BD}$, twice a day; $\mathrm{TD}$, thrice a day; $\mathrm{Cl}$, confidence interval; $\mathrm{EC} 50$, Half maximal effective concentration; $\mathrm{CC} 50,50 \%$ cytotoxic concentration. $\mathrm{SI}$, selectivity index.

systemic and discoid lupus erythematosus, sarcoidosis, scleroderma, pemphigus porphyria cutanea tarda. ${ }^{63}$ Despite drugs' adverse effects on humans, such as cardiac, retinal, and neuromuscular toxicities, their benefits outweigh the toxicity effects. ${ }^{64,65}$ The CQ and HCQ have also been tested to treat various diseases such as human immunodeficiency diseases, Q fever, whipple disease, and fungal infection. ${ }^{65,66}$ These drugs have several other beneficial properties, including anti-inflammatory, immuno-modulating, anti-infective, anti-thrombotic, and anti-tumoral properties. ${ }^{65}$

Due to these multifaceted effects of CQ and HCQ, including antiviral properties, these drugs have been extensively investigated against the SARS-COV-2 virus and COVID-19 patients, and the outcomes widely varied. Indeed, few in vitro investigations have revealed antiviral influences against SARS-COV-2., ${ }^{3,27,28}$ The results are preliminary based on the small clinical trials and usually cofounding with pre-existing comorbidities, age, and severity of disease. ${ }^{51}$

The prophylaxis use of CQ and HCQ did not show any clinical efficacy in randomized controlled trials. In most cases, there is a lack of randomized control trials with longterm supervision of the patients and their contacts to explore the efficacy of $\mathrm{CQ} / \mathrm{HCQ}$ for postexposure prophylaxis. Many times, its toxicity, particularly cardiac toxicities, outweighed its benefits, unlike the treatment of malarial infection. A recent meta-analysis of 12 studies showed no evidence of clinical benefit from $\mathrm{CQ} / \mathrm{HCQ}$ administration in COVID-19 patients. $^{35}$ Other limitations of this regimen were (1) the potential interaction with azithromycin and several other medications leading to QT prolongation and possible cardiovascular side effects and (2) the hypoglycemia if not adequately monitored in diabetic patients. While close monitoring might optimize is regimen's safety, the safety profile does not make it suitable for a pandemic situation. With several cases overwhelming the healthcare systems, it becomes unpractical to screen all patients for the potential interactions in the clinical setting. Future directions in the CQ/HCQ drugs might include improved drug delivery either by inhalation ${ }^{67}$ or transcatheter delivery through the bronchial artery. ${ }^{68}$

The randomized and controlled WHO Solidarity ${ }^{69}$ trial did not find an effectiveness of HCQ in reducing mortality rate (risk ratio of $1.19 ; P=0.23$ ) among the hospitalized COVID-19 patients. Based on lack of benefits of using $\mathrm{HCQ}, \mathrm{WHO}^{54}$ and National Institute of Health had stopped trial for hospitalized COVID patients. ${ }^{61}$ A recent randomized controlled trial by Horby et $\mathrm{al}^{61}$ in the UK comprising 4716 COVID-19 patients showed that administration of HCQ had no benefits in decreasing death rate (rate ratio of $1.09 ; P=0.15$ ).

Moreover, a recent meta-analysis based on 28 randomized trial containing 10.012 COVID-19 patients treated with HCQ, 307 patients with CQ and 63 patients with both CQ and HCQ in which WHO Solidarity ${ }^{69}$ and RECOVERY $^{61}$ included that HCQ treatment was associated with increased (risk ratio of $1.11 ; P=0.02$ ) mortality rate, whereas $\mathrm{CQ}$ did not show (risk ratio of $1.77 ; P=$ 0.21 ) any benefit in reducing mortality rate. ${ }^{70}$ Finally, according to new data from two large RCTs (Recovery and Solidarity), the United States Food and Drug Administration (FDA) revoked the CQ/HCQ regimen's emergency usage authorization in COVID-19 patients. 
The drugs are currently used for clinical trial purposes only. $^{21}$ Furthermore, we searched clinicaltrials.gov for clinical trials on COVID-19 using the keywords: "chloroquine OR hydroxychloroquine". Then, we filtered the records to identify the "ongoing studies only". The search retrieved 97 ongoing studies; the summary of the 97 ongoing studies and their characteristics are provided in the Supplementary Table S1.

\section{Conclusion and Recommendations}

Based on the initial early experimental data of CQ and HCQ for treatment of SARS-CoV-2, the regimen received an emergency usage authorization from the FDA for COVID19 on March 28, 2020. However, the two largest RCTs data to date showed no clinical advantage of HCQ treatment in COVID-19 patients. As a result, the FDA revoked the emergency use authorization of this regimen. In terms of prophylaxis, one RCT showed no evidence of post-exposure prevention from COVID-19. Despite the initial promising findings in the in vitro studies and the widespread use of $\mathrm{CQ} /$ HCQ in clinical settings during the $1^{\text {st }}$ wave of COVID-19, current data from well-designed randomized controlled trials showed no evidence of benefit from CQ/HCQ supplementation for the treatment or prophylaxis against SARS-CoV-2 infection. Particularly, the two largest randomized controlled trials to date (RECOVERY ${ }^{61}$ and WHO SOLIDARITY ${ }^{69}$ ), both confirmed that $\mathrm{CQ} / \mathrm{HCQ}$ regimen does not provide any clinical benefit for COVID-19 patients. Therefore, we do not recommend the use of this regimen in COVID-19 patients outside the context of clinical trials.

\section{Data Sharing Statement}

This review article is based on the published available literature.

\section{Author Contributions}

All authors (S.S., N.A., M.A., Y.A., S.A., S.S.E., M.S., O. A., N.A., A.A., O.A., A.K.P., A.K., A.N., A.N., W.A-A., A.A.A., K.A.E.-T. and M. A.E.-H.) have made a significant contribution to this review article. They all equally shared in the conception, study design, execution, acquisition of data, analysis and interpretation. S.S., N.A., M.A., Y.A., S.A., S.S.E., K.A.E.-T, and M.A.E.-H. have drafted the manuscript. M.S., O.A., N.A., A.A., O.A., A.K. P., A.K., A.N., A.N., W.A-A., A.A.A., K.A.E.-T. have substantially revised and critically reviewed the article. All authors have agreed on the submission to this journal and agreed on all versions of the article before submission or during revisions. All authors agreed to take responsibility and be accountable for the contents of this article.

\section{Funding}

No funding.

\section{Disclosure}

The authors report no conflicts of interest for this work and declare that the research was conducted in the absence of any commercial or financial relationships that could be construed as a potential conflict of interest.

\section{References}

1. WHO. Naming the coronavirus disease (COVID-19) and the virus that causes it. 2020a. Available from: https://www.who.int/emergen cies/diseases/novel-coronavirus-2019/technical-guidance/naming-thecoronavirus-disease-(covid-2019)-and-the-virus-that-causes-it. Accessed April 9, 2021

2. WHO. Coronavirus disease (COVID-19) Weekly Epidemiological Update. 2020b; 1-22. Available from: https://www.who.int/docs/ default-source/coronaviruse/situation-reports/20200831-weekly-epiupdate-3.pdf?sfvrsn=d7032a2a_4. Accessed April 9, 2021.

3. Liu J, Cao R, Xu M, et al. Hydroxychloroquine, a less toxic derivative of chloroquine, is effective in inhibiting SARS-CoV-2 infection in vitro. Cell Discov. 2020;6:16. doi:10.1038/s41421-020-0156-0

4. Chan JF, Kok KH, Zhu Z, et al.. Genomic characterization of the 2019 novel human-pathogenic coronavirus isolated from a patient with atypical pneumonia after visiting Wuhan. Emerg Microbes Infect. 2020;9:221-236. doi:10.1080/22221751.2020.1719902

5. Chen J. Pathogenicity and transmissibility of 2019-nCoV. A quick overview and comparison with other emerging viruses. Microbes Infect. 2020;22:69-71. doi:10.1016/j.micinf.2020.01.004

6. Schrezenmeier E, Dörner T. Mechanisms of action of hydroxychloroquine and chloroquine: implications for rheumatology. Nat Rev Rheumatol. 2020;16:155-166. doi:10.1038/s41584-020-0372-x

7. Andersag H. Antimalariamittel aus der Gruppe halogensubstituierter Chinolinverbindungen [Antimalarials from the group of halogen-substituted quinoline compounds]. Chem Ber. 1948;81:499507. German. doi:10.1002/cber.19480810607

8. Drake NL, Creech HJ, Garman JA, et al. Synthetic antimalarials. The preparation of certain 4-aminoquinolines. $J$ Am Chem Soc. 1946;68:1208-1213. doi:10.1021/ja01211a021

9. McChesney EW. Animal toxicity and pharmacokinetics of hydroxychloroquine sulfate. Am J Med. 1983;75:11-18. doi:10.1016/00029343(83)91265-2

10. Colson P, Rolain J-M, Lagier J-C, et al. Chloroquine and hydroxychloroquine as available weapons to fight COVID-19. Int J Antimicrob Agents. 2020;55:105932. doi:10.1016/j.ijantimicag.2020.105932

11. Kumar R, Srivastava JK, Singh R, et al.. Available compounds with therapeutic potential against Covid-19: antimicrobial therapies, supportive care, and probable vaccines. Front Pharmacol. 2020;6:582025. doi:10.3389/fphar.2020.582025

12. Chen L, Chen H, Dong S, et al. The effects of chloroquine and hydroxychloroquine on ACE2-related coronavirus pathology and the cardiovascular system: an evidence-based review. Function. 2020a;1:zqaa012. doi:10.1093/function/zqaa012

13. Fantini J, Di Scala C, Chahinian H, Yahi N. Structural and molecular modelling studies reveal a new mechanism of action of chloroquine and hydroxychloroquine against SARS-CoV-2 infection. Int $J$ Antimicrob Agents. 2020;55:105960. doi:10.1016/j.ijantimicag.2020.105960 
14. Goel P, Gerriets V. Chloroquine. In: StatPearls [Internet]. Treasure Island (FL): StatPearls Publishing; 2020. Available from https://www. ncbi.nlm.nih.gov/books/NBK551512/. Accessed April 9, 2021.

15. Braga CBE, Martins AC, Cayotopa ADE, et al. Side effects of chloroquine and primaquine and symptom reduction in malaria endemic area (Mâncio lima, Acre, Brazil). Interdiscip Perspect Infect Dis. 2020;2015:346853. doi:10.1155/2015/346853

16. Kumar R, Sharma A, Srivastava JK, Siddiqui MH, Uddin MS, Aleya L. Hydroxychloroquine in COVID-19: therapeutic promises, current status, and environmental implications. Environ Sci Pollut Res Int. 2021;15:1-14. doi:10.1007/s11356-020-12200-1

17. White NJ. Cardiotoxicity of antimalarial drugs. Lancet Infect Dis. 1998;7:549-558. doi:10.1016/S1473-3099(07)70187-1

18. Juurlink DN. Safety considerations with chloroquine, hydroxychloroquine and azithromycin in the management of SARS-CoV-2 infection. CMAJ. 2020;192:E450-E453. doi:10.1503/cmaj.200528

19. Sahraei Z, Shabani M, Shokouhi S, Saffaei A. Aminoquinolines against coronavirus disease 2019 (COVID-19): chloroquine or hydroxychloroquine. Int $J$ Antimicrob Agents. 2020;55:105945. doi:10.1016/j.ijantimicag.2020.105945

20. Singh AK, Singh A, Shaikh A, Singh R, Misra A. Chloroquine and hydroxychloroquine in the treatment of COVID-19 with or without diabetes: a systematic search and a narrative review with a special reference to India and other developing countries. Diabetes Metab Syndr Clin Res Rev. 2020;14:241-246. doi:10.1016/j.dsx.2020.03.011

21. FDA, USA. ARALEN®. Chloroquine phosphate, USP. US FDA, for malaria and extraintestinal amebiasis. 2020; 1-8. Reference ID: 3402523

22. Gautret P, Lagier J-C, Parola P, et al. Hydroxychloroquine and azithromycin as a treatment of COVID-19: results of an open-label non-randomized clinical trial. Int $J$ Antimicrob Agents. 2020; 56:105949. doi:10.1016/j.ijantimicag.2020.105949

23. Chorin E, Wadhwani L, Magnani S, et al. QT interval prolongation and torsade de pointes in patients with COVID-19 treated with hydroxychloroquine/azithromycin. Heart Rhythm. 2020a;17:142 5-1433. doi:10.1016/j.hrthm.2020.05.014

24. Cortegiani A, Ingoglia G, Ippolito M, Giarratano A, Einav S. A systematic review on the efficacy and safety of chloroquine for the treatment of COVID-19. J Crit Care. 2020;57:279-283. doi:10. 1016/j.jcrc.2020.03.005

25. Dashraath P, Wong JL, Lim MX, et al. Coronavirus disease 2019 (COVID-19) pandemic and pregnancy. Am J Obstet Gynecol. 2020;6:521-531. doi:10.1016/j.ajog.2020.03.021

26. Shah K, Tiwaskar M, Chawla P, et al. Hypoglycemia at the time of COVID-19 pandemic. Diabetes Metab Syndr Clin Res Rev. 2020;14:1143-1146. doi:10.1016/j.dsx.2020.07.003

27. Wang M, Cao R, Zhang L, et al. Remdesivir and chloroquine effectively inhibit the recently emerged novel coronavirus (2019-nCoV) in vitro. Cell Res. 2020;30:269-271. doi:10.1038/s41422-020-0282-0

28. Yao X, Ye F, Zhang M, et al. In vitro antiviral activity and projection of optimized dosing design of hydroxychloroquine for the treatment of severe acute respiratory syndrome coronavirus 2 (SARS-CoV-2). Clin Infect Dis. 2020;71:723-739. doi:10.1093/cid/ciaa237

29. Cohen MS. Hydroxychloroquine for the prevention of Covid-19searching for evidence. $N$ Engl $J$ Med. 2020;383:585-586. doi:10.1056/NEJMe2020388

30. Tilangi P, Desai D, Khan A, Soneja M. Hydroxychloroquine prophylaxis for high-risk COVID-19 contacts in India: a prudent approach. Lancet Infect Dis. 2020;20:1119-1120. doi:10.1016/S1473-3099(20) 30430-8

31. Boulware DR, Pullen MF, Bangdiwala AS, et al. A randomized trial of hydroxychloroquine as postexposure prophylaxis for Covid-19. N Engl J Med. 2020;383:517-525. doi:10.1056/NEJMoa2016638

32. Iyer M, Jayaramayya K, Subramaniam MD, et al. COVID-19: an update on diagnostic and therapeutic approaches. BMB Rep. 2020;53:191-205. doi:10.5483/BMBRep.2020.53.4.080
33. Jian G, Jun L, Xu S, et al. Anti-inflammatory and immunoregulatory effects of total glucosides of Yupingfeng powder. Chin Med J (Engl). 2009;122:1636-1641. doi:10.3760/cma.j.issn.0366-6999.2009.14.007

34. Gao J, Tian Z, Yang X. Breakthrough: chloroquine phosphate has shown apparent efficacy in treatment of COVID-19 associated pneumonia in clinical studies. Biosci Trends. 2020;14:72-73. doi:10.5582/ bst. 2020.01047

35. Ullah W, Abdullah MH, Roomi S, et al. Safety and efficacy of hydroxychloroquine in COVID-19: a systematic review and meta-analysis. J Clin Med Res. 2020;12:483-491. doi:10.14740/ jocmr4233

36. Ranganathan P, Pramesh C, Aggarwal R. Common pitfalls in statistical analysis: intention-to-treat versus per-protocol analysis. Perspect Clin Res. 2016;7:144-146. doi:10.4103/2229-3485.184823

37. Dumas-Mallet E, Button KS, Boraud T, Gonon F, Munafo MR. Low statistical power in biomedical science: a review of three human research domains. R Soc Open Sci. 2017;4:160254. doi:10.1098/ rsos. 160254

38. Chen J, Liu D, Liu L, et al. A pilot study of hydroxychloroquine in treatment of patients with moderate COVID-19. J. Zhejiang. Univ. (Medical Sci.). 2020b;49:215-219. doi:10.3785/j.issn.1008-9292.20 20.03.03

39. Kim AHJ, Sparks JA, Liew JW, et al. A rush to judgment? Rapid reporting and dissemination of results and its consequences regarding the use of hydroxychloroquine for COVID-19. Ann Intern Med. 2020;172:819-821. doi:10.7326/m20-1223

40. Dahly D, Gates S, Morris T. Statistical review of hydroxychloroquine and azithromycin as a treatment of COVID-19: results of an open-label non-randomized clinical trial. 2020. doi:10.5281/ zenodo. 3724167

41. Dong L, Hu S, Gao J. Discovering drugs to treat coronavirus disease 2019 (COVID-19). Drug Discov Ther. 2020;14:58-60. doi:10.5582/ ddt.2020.01012

42. Nicastri E, Petrosillo N, Bartoli T, et al. National institute for the infectious diseases "L. Spallanzani" IRCCS. Recommendations for COVID-19 clinical management. Infect Dis Rep. 2020;12:8543. doi:10.4081/idr.2020.8543

43. Perinel S, Launay M, Botelho-Nevers E, et al. Towards optimization of hydroxychloroquine dosing in intensive care unit COVID-19 Patients. Clin Infect Dis. 2020;7:ciaa394. doi:10.1093/cid/ciaa394

44. Garcia-Cremades M, Solans BP, Hughes E, et al. Optimizing hydroxychloroquine dosing for patients with COVID-19: an integrative modeling approach for effective drug repurposing. Clin Pharmacol Ther. 2020;108:253-263. doi:10.1002/cpt.1856

45. Catteau L, Dauby N, Montourcy M, et al. Low-dose hydroxychloroquine therapy and mortality in hospitalised patients with COVID-19: a nationwide observational study of 8075 participants. Int $J$ Antimicrob Agents. 2020;4:106144. doi:10.1016/j.ijantimicag. 2020.106144

46. Lee SH, Son H, Peck KR. Can post-exposure prophylaxis for COVID-19 be considered as an outbreak response strategy in long-term care hospitals?. Int J Antimicrob Agents. 2020;55:105988. doi:10.1016/j.ijantimicag.2020.105988

47. Neurath MF. COVID-19 and immunomodulation in IBD. Gut. 2020;69:1335-1342. doi:10.1136/gutjnl-2020-321269

48. Chen CY, Wang FL, Lin CC. Chronic hydroxychloroquine use associated with QT prolongation and refractory ventricular arrhythmia. Clin Toxicol. 2006;44:173-175. doi:10.1080/15563650500514558

49. Chorin E, Dai M, Shulman E, et al. The QT interval in patients with COVID-19 treated with hydroxychloroquine and azithromycin. Nat Med. 2020b;26:808-809. doi:10.1038/s41591-020-0888-2

50. Borba MGS, Val FFA, Sampaio VS, et al. Effect of high vs low doses of chloroquine diphosphate as adjunctive therapy for patients hospitalized with severe acute respiratory syndrome Coronavirus 2 (SARS-CoV-2) infection. A randomized clinical trial. JAMA Netw Open. 2020;3:e208857. doi:10.1001/jamanetworkopen.2020.8857 
51. Mathian A, Mahevas M, Rohmer J, et al. Clinical course of coronavirus disease 2019 (COVID-19) in a series of 17 patients with systemic lupus erythematosus under long-term treatment with hydroxychloroquine. Ann Rheum Dis. 2020;79:837-839. doi:10.11 36/annrheumdis-2020-217566

52. Savarino A, Boelaert JR, Cassone A, et al. Effects of chloroquine on viral infections: an old drug against today's diseases?. Lancet Infect Dis. 2003;3:722-727. doi:10.1016/S1473-3099(03)00806-5

53. Horby P, Landray M No clinical benefit from use of hydroxychloroquine in hospitalised patients with COVID-19. 2020. Available from: https://www.ox.ac.uk/news/2020-06-05-no-clinical-benefit-usehydroxychloroquine-hospitalised-patients-covid-19guidance/namingthe-coronavirus-disease-(covid-2019)-and-the-virus-that-causes-it

54. WHO. WHO discontinues hydroxychloroquine and lopinavir/ritonavir treatment arms for COVID-19. 2020c. Available from: www.who. int/news-room/detail/04-07-2020-who-discontinueshydroxychloroquine-and-lopinavir-ritonavir-treatment-arms-forcovid-19

55. Van-den Broek MPH, Möhlmann JE, Abeln BGS, Liebregts M, Vandijk VF, Van-de Grade EM. Chloroquine-induced QTc prolongation in COVID-19 patients. Neth Heart J. 2020;28:406-409. doi:10.1007/ s12471-020-01429-7

56. Geleris J, Sun Y, Platt J, et al. Observational study of hydroxychloroquine in hospitalized patients with Covid-19. N Engl J Med. 2020;382:2411-2418. doi:10.1056/NEJMoa2012410

57. Magagnoli J, Narendran S, Pereira F, et al. Outcomes of hydroxychloroquine usage in United States veterans hospitalized with Covid-19. Med. 2020;1:114-127. doi:10.1016/j.medj.2020.06.001

58. Mahevas M, Tran VT, Roumier M, et al. No evidence of clinical efficacy of hydroxychloroquine in patients hospitalized for COVID-19 infection with oxygen requirement: results of a study using routinely collected data to emulate a target trial. BJM. 2020;369:m1844. doi:10.1101/2020.04.10.20060699

59. Rosenberg ES, Dufort EM, Udo T, et al. Association of treatment with hydroxychloroquine or azithromycin with in-hospital mortality in patients with COVID-19 in New York state. JAMA. 2020;323:2493-2502. doi:10.1001/jama.2020.8630
60. Yu B, Wang DW, Li C. Hydroxychloroquine application is associated with a decreased mortality in critically ill patients with COVID-19. MedRxiv. 2020;20073379. doi:10.1101/2020.04.27.20073379

61. Horby P, Mafham M, Linsell L, et al. Effect of hydroxychloroquine in hospitalized patients with Covid-19. $N$ Engl J Med. 2020;383:2030-2040. doi:10.1056/NEJMoa2022926

62. Skipper CP, Pastick KA, Engen NW, et al. Hydroxychloroquine in nonhospitalized adults with early COVID-19. Ann Intern Med. 2020;173:623-631. doi:10.7326/M20-4207

63. Mushtaque M. Reemergence of chloroquine (CQ) analogs as multi-targeting antimalarial agents: a review. Eur J Med Chem. 2015;90:280-295. doi:10.1016/j.ejmech.2014.11.022

64. Taylor WRJ, White NJ. Antimalarial drug toxicity. Drug Saf. 2004;27:25-61. doi:10.2165/00002018-200427010-00003

65. Plantone D, Koudriavtseva T. Current and future use of chloroquine and hydroxychloroquine in infectious, immune, neoplastic, and neurological diseases: a mini-review. Clin Drug Investig. 2018;38: 653-671. doi:10.1007/s40261-018-0656-y

66. Bonam SR, Muller S, Bayry J, Klionsky DJ. Autophagy as an emerging target for COVID-19: lessons from an old friend, chloroquine. Autophagy. 2020;16:2260-2266. doi:10.1080/15548627.2020.177 9467

67. Tai TT, Wu TJ, Wu HD, et al. A strategy to treat COVID-19 disease with targeted delivery of inhalable liposomal hydroxychloroquine: a non-clinical pharmacokinetic study. Clin Transl Sci. 2020;14 (1):132-136. doi:10.1101/2020.07.09.196618

68. Zaitoun MMA, Basha MAA, Elmokadem AH. Transcatheter drug delivery through bronchial artery for COVID-19: is it fiction or could it come true?. Eur Radiol Exp. 2020;4:42. doi:10.1186/s41747-02000171-4

69. Pan H, Peto R, AbdoolKarim Q, et al. Repurposed antiviral drugs for COVID-19; interim WHO solidarity trial results. $N$ Engl J Med. 2021;384:497-511. doi:10.1056/NEJMoa2023184

70. Axfors C, Schmitt AM, Janiaud P, et al.. Mortality outcomes with hydroxychloroquine and chloroquine in COVID-19: an international collaborative meta-analysis of randomized trials. MedRxiv. 2020:20194571. doi:10.1101/2020.09.16.20194571.
Therapeutics and Clinical Risk Management

\section{Publish your work in this journal}

Therapeutics and Clinical Risk Management is an international, peerreviewed journal of clinical therapeutics and risk management, focusing on concise rapid reporting of clinical studies in all therapeutic areas, outcomes, safety, and programs for the effective, safe, and sustained use of medicines. This journal is indexed on PubMed Central, CAS,
EMBase, Scopus and the Elsevier Bibliographic databases. The manuscript management system is completely online and includes a very quick and fair peer-review system, which is all easy to use. Visit http://www.dovepress.com/testimonials.php to read real quotes from published authors. 